\title{
Syntheses and structures of chalcogen-bridged binuclear group 5 and 6 metal complexes
}

\author{
MOULIKA BHATTACHARYYA ${ }^{\mathrm{a}}$, RINI PRAKASH ${ }^{\mathrm{a}}$, CHANDAN NANDI ${ }^{\mathrm{a}}$, \\ MONOJIT GHOSAL CHOWDHURY ${ }^{\mathrm{a}}$, BEESAM RAGHAVENDRA ${ }^{\mathrm{a}}$, THIERRY ROISNEL $^{\mathrm{b}}$ and \\ SUNDARGOPAL GHOSH ${ }^{\mathrm{a}, *}$ (D) \\ ${ }^{a}$ Department of Chemistry, Indian Institute of Technology Madras, Chennai 600 036, Tamilnadu, India \\ ${ }^{\mathrm{b}}$ CNRS, ISCR (Institut des Sciences Chimiques de Rennes) - UMR 6226, Univ Rennes, 35000 Rennes, \\ France \\ E-mail: sghosh@iitm.ac.in
}

MS received 10 June 2019; revised 22 October 2019; accepted 23 October 2019; published online 5 December 2019

\begin{abstract}
Syntheses and structural elucidations of a series of chalcogen stabilized binuclear complexes of group 5 and 6 transition metals have been described. Room temperature reaction of $\left[\mathrm{Cp}^{*} \mathrm{CrCl}\right]_{2}\left(\mathrm{Cp} *=\eta^{5}-\right.$ $\left.\mathrm{C}_{5} \mathrm{Me}_{5}\right)$ with $\mathrm{Li}\left[\mathrm{BH}_{3}(\mathrm{SePh})\right]$ afforded a Se inserted binuclear chromium complex, $\left[(\mathrm{Cp} * \mathrm{Cr})_{2}\left(\mu-\mathrm{Se} \mathrm{SePh}_{2}\right], \mathbf{1}\right.$. In an attempt to make the analogous complexes with heavier group 6 metals, reactions of $\left[\mathrm{Cp}^{*} \mathrm{MCl}_{4}\right]$ $(\mathrm{M}=\mathrm{Mo}$ and $\mathrm{W})$ with $\mathrm{Li}\left[\mathrm{BH}_{3}(\mathrm{SePh})\right]$ were carried out that yielded Se inserted binuclear complexes $\left[(\mathrm{Cp} * \mathrm{M})_{2}(\mu-\mathrm{Se})_{2}(\mu-\mathrm{SePh})_{2}\right], 2$ and $\mathbf{3}(\mathbf{2}: \mathrm{M}=\mathrm{Mo}$ and 3: $\mathrm{M}=\mathrm{W})$ along with known $\left[\left(\mathrm{Cp}^{*} \mathrm{M}\right)_{2} \mathrm{~B}_{5} \mathrm{H}_{9}\right], \mathbf{4 a}_{-}$ b (4a: $\mathrm{M}=\mathrm{Mo}$ and $\mathbf{4 b}: \mathrm{M}=\mathrm{W})$. Similarly, the reactions of $\left[\mathrm{Cp}^{*} \mathrm{NbCl}_{4}\right]$ with $\mathrm{Li}\left[\mathrm{BH}_{3}(\mathrm{EPh})\right](\mathrm{E}=\mathrm{S}$ or $\mathrm{Se})$ followed by thermolysis led to the formation of binuclear chalcogen complexes $\left[(\mathrm{Cp} * \mathrm{Nb})_{2}\left(\mu-\mathrm{E}_{2}\right)_{2}\right], \mathbf{5}$ and $\mathbf{6}$ (5: $\mathrm{E}=\mathrm{S}$ and 6: $\mathrm{E}=\mathrm{Se})$ and known $\left[(\mathrm{Cp} * \mathrm{Nb})_{2}\left(\mathrm{~B}_{2} \mathrm{H}_{6}\right)_{2}\right]$, 7. All these complexes have been characterized by ${ }^{1} \mathrm{H}$ and ${ }^{13} \mathrm{C}$ NMR spectroscopy and mass spectrometry. The structural integrity of complexes $\mathbf{1}, \mathbf{3}, \mathbf{5}$ and $\mathbf{6}$ was established by the X-ray diffraction studies. The DFT studies further exemplify the bonding interactions present in these complexes, especially the multiple bond character between the metals in 1-3.
\end{abstract}

Keywords. Chalcogen; binuclear complex; chalcogen-bridged.

\section{Introduction}

Transition metal complexes possessing chalcogen ligands have gained considerable attention due to their potential applications in chemical and biological systems. ${ }^{1,2}$ In parallel to the other transition metal-main group complexes, ${ }^{3,4}$ chalcogenide bridged molecular complexes also attracted importance due to their unusual stability, structural variety and catalytic applications. ${ }^{5-7}$ Extensive studies unveiled the superior reactivity associated with transition metal sulfido complexes towards alkene, alkyne and dihydrogen. ${ }^{8-10}$ Particularly for early transition metals, the "electron sink" properties of the chalcogenide cores associated with their structural and electronic diversity established the interesting aspects of such complexes. In this regard, thio complexes of vanadium and molybdenum-containing cyclopentadienyl ligands exhibited rich chemistry and interesting electronic properties. ${ }^{11,12}$ Dinuclear cyclopentadienyl-molybdenum and rhenium complexes containing bridging sulfido and disulfido ligands such as $\left[(\mathrm{MeCp})_{2} \mathrm{Mo}_{2}\left(\mu-\mathrm{S}_{2}\right)(\mu-\mathrm{S})_{2}\right]$ $\left(\mathrm{Cp}=\eta^{5}-\mathrm{C}_{5} \mathrm{H}_{5}\right)$ and $\left[\left(\mathrm{Cp}^{\prime}\right)_{2} \operatorname{Re}_{2}\left(\mu-\mathrm{S}_{2}\right)_{2}\right]^{2+}\left(\mathrm{Cp}^{\prime}=\eta^{5}-\right.$ $\mathrm{C}_{5} \mathrm{Me}_{4} \mathrm{Et}$ ) showed interesting structures and reactivity. ${ }^{13}$ The facile reactivity of $\left[\mathrm{Cp}_{2} \mathrm{Mo}_{2} \mathrm{~S}_{4}\right]$ towards $\mathrm{H}_{2}$ under ambient conditions yielded bis(hydrosulfide) complex $\left[\mathrm{Cp}_{2} \mathrm{Mo}_{2}(\mu-\mathrm{S})_{2}(\mu-\mathrm{SH})_{2}\right] .{ }^{14}$ The reactions of alkenes or alkynes with $\left[\mathrm{Cp}_{2} \mathrm{Mo}_{2}(\mu-\mathrm{S})_{2}\left(\mu-\eta^{2}-\mathrm{SH}\right)_{2}\right]$ generated bis-dithiolate complexes with exciting structural aspects. ${ }^{15}$ Also, the study of the structure and magnetic properties of the mixed-metal chalcogenide-containing clusters has been a topic of intense

*For correspondence

Electronic supplementary material: The online version of this article (https://doi.org/10.1007/s12039-019-1703-9) contains supplementary material, which is available to authorized users. 
research interest in modelling the action of natural metalloenzymes. ${ }^{16}$ A significant effect of the chalcogen bridge atom on the magnetic properties of the cluster have been observed for antiferromagnetic homo- and heterochalcogenide complexes. ${ }^{17}$

Among the presently known metal-chalcogen complexes, group 6 metals are well explored, especially Mo and W. ${ }^{18 \mathrm{a}-\mathrm{e}}$ Apart from their importance in biology and catalysis, ${ }^{18 f-h}$ these complexes also demonstrated the presence of unique conformational isomers. Similar to group 6, binuclear complexes of group 5 are also known, albeit lesser number. ${ }^{19,20}$ Not only structural point of view, unsupported $\mathrm{NbS}_{3}$ complexes containing $\left\{\mathrm{Nb}_{2}\left(\mu-\mathrm{S}_{2}\right)(\mu-\mathrm{S})\right\}$ unit found its application as a catalyst in thiophene hydrodesulfurization. ${ }^{21}$ Binuclear sulfide complex $\left(\mathrm{Et}_{4} \mathrm{~N}\right)_{2}\left[\mathrm{Nb}_{2} \mathrm{~S}_{4}(\mathrm{NCS})_{6}\right.$ (bipy)] coordinated by diimine ligand revealed photocatalytic and optical limiting properties. ${ }^{22}$ However, it is important to note that, although dinuclear complexes of early transition metals containing bridging sulfur ligands are well known, structurally characterized heavier chalcogen inserted cyclopentadienyl binuclear complexes are relatively less.

Apart from chalcogen powders or organo-chalcogenides, ${ }^{23,24}$ we have established that the chalcogenated borohydrides can also be used as a potential reagent for the synthesis of binuclear chalcogen complexes along with dimetallaheteroboranes. ${ }^{25-27}$ Hence, to extend this strategy for group 5 and 6 metals we have performed the reactivity of $\left[\mathrm{Cp}^{*} \mathrm{CrCl}\right]_{2}$ and $\left[\mathrm{Cp}^{*} \mathrm{MCl}_{4}\right](\mathrm{M}=\mathrm{Mo}, \mathrm{W}$ and $\mathrm{Nb})$ with $\mathrm{Li}\left[\mathrm{BH}_{3}(\mathrm{EPh})\right]$ $(\mathrm{E}=\mathrm{S}$ and $\mathrm{Se})$. In this report, we describe the synthesis of various chalcogen-bridged binuclear complexes furnishing interesting structural aspects. In addition, theoretical studies have been performed on these molecules to elucidate their bonding nature.

\section{Experimental}

\subsection{General considerations}

All of the operations were conducted under an $\mathrm{Ar} / \mathrm{N}_{2}$ atmosphere by using standard Schlenk techniques or in a glove box. Solvents were distilled prior to use under Ar atmosphere. [ $\left[\mathrm{LiBH}_{4} \cdot \mathrm{THF}\right],\left[\mathrm{Ph}_{2} \mathrm{~S}_{2}\right]$ and $\left[\mathrm{Ph}_{2} \mathrm{Se}_{2}\right]$ were used as received (Aldrich). $[\mathrm{Cp} * \mathrm{CrCl}]_{2},{ }^{28}$ $\left[\mathrm{Cp} * \mathrm{MoCl}_{4}\right],{ }^{29 \mathrm{a}} \quad\left[\mathrm{Cp} * \mathrm{WCl}_{4}\right],{ }^{29 \mathrm{~b}} \quad\left[\mathrm{Cp} * \mathrm{NbCl}_{4}\right],{ }^{30}$ $\mathrm{Li}\left[\mathrm{BH}_{3}(\mathrm{EPh})\right]^{26 \mathrm{~b}}(\mathrm{E}=\mathrm{S}$ or $\mathrm{Se})$ and the external reference for ${ }^{11} \mathrm{~B}$ NMR is $\left[\mathrm{Bu}_{4} \mathrm{~N}\left(\mathrm{~B}_{3} \mathrm{H}_{8}\right)\right]^{31}$ were synthesized according to the literature methods available. Thin layer chromatography (TLC) was carried out on $250-\mu \mathrm{m}$ diameter aluminum supported silica gel TLC plates (MERCK TLC Plates) to separate the reaction mixtures. The NMR spectra were recorded on 500 or $400 \mathrm{MHz}$ Bruker FT-NMR spectrometer. Residual solvent protons were used as reference $\left(\mathrm{CDCl}_{3}\right.$, $\left.\delta=7.26 \mathrm{ppm}, \mathrm{C}_{6} \mathrm{D}_{6}, \delta=7.16 \mathrm{ppm}\right)$, while a sealed tube that contained, $\left[\mathrm{Bu}_{4} \mathrm{~N}\left(\mathrm{~B}_{3} \mathrm{H}_{8}\right)\right]$ in $\left[\mathrm{D}_{6}\right]$-benzene $\left(\delta_{\mathrm{B}}=-30.07 \mathrm{ppm}\right)$ was used as an external reference for the ${ }^{11} \mathrm{~B}\left\{{ }^{1} \mathrm{H}\right\}$ NMR analysis. Mass spectra were recorded with a BrukerMicroTOF-II mass spectrometer and Qtof Micro YA263 HRMS instrument in ESI ionization mode. Infrared spectra were recorded with a JASCO FT/IR-4100 spectrometer. Absorption spectra were recorded with Jasco V-650 UV/Vis spectrophotometers at $298 \mathrm{~K}$.

\subsection{Synthesis of $\mathbf{1 - 4}$}

A suspension of $\left[\mathrm{Cp}^{*} \mathrm{CrCl}\right]_{2}(0.5 \mathrm{~g}, 1.12 \mathrm{mmol})$ in $10 \mathrm{~mL}$ toluene at $-78^{\circ} \mathrm{C}$ was charged dropwise with a freshly prepared solution of $\mathrm{Li}\left[\mathrm{BH}_{3}(\mathrm{SePh})\right]$ $(2.24 \mathrm{mmol})$ over $15 \mathrm{~min}$. The $\mathrm{Li}\left[\mathrm{BH}_{3}(\mathrm{SePh})\right]$ solution was prepared from the reaction of $\left[\mathrm{Ph}_{2} \mathrm{Se}_{2}\right]$ with $\mathrm{LiBH}_{4} \cdot \mathrm{THF}$ at ice-cooled temperature. The reaction mixture was then stirred at room temperature for $20 \mathrm{hrs}$. The solvent was dried and the residue was extracted into $n$-hexane/ $\mathrm{CH}_{2} \mathrm{Cl}_{2}$ and passed through Celite. After removal of the solvent, the residue was subjected to chromatographic work-up by using TLC plates ( $n$-hexane $\left./ \mathrm{CH}_{2} \mathrm{Cl}_{2}, 50: 50 \mathrm{v} / \mathrm{v}\right)$ to yield complex $\left[(\mathrm{Cp} * \mathrm{Cr})_{2}\left(\mu-\mathrm{Se}_{2} \mathrm{SePh}\right)_{2}\right], 1(0.078 \mathrm{~g}, 7 \%)$, as violet solid. Along with 1 few air and moisture sensitive complexes are also formed which we were unable to isolate.

Under the similar experimental conditions, treatment of $\mathrm{Li}\left[\mathrm{BH}_{3}(\mathrm{SePh})\right](2.16 \mathrm{mmol})$ with $\left[\mathrm{Cp}^{*} \mathrm{MoCl}_{4}\right]$ $(0.2 \mathrm{~g}, 0.54 \mathrm{mmol})$ and reaction of $\mathrm{Li}\left[\mathrm{BH}_{3}(\mathrm{SePh})\right]$ $(1.72 \mathrm{mmol})$ with $\left[\mathrm{Cp}^{*} \mathrm{WCl}_{4}\right](0.2 \mathrm{~g}, 0.43 \mathrm{mmol})$ for $4 \mathrm{hrs}$ yielded $\left[(\mathrm{Cp} * \mathrm{Mo})_{2}(\mu-\mathrm{Se})_{2}(\mu-\mathrm{SePh})_{2}\right], 2(0.02 \mathrm{~g}$, $8 \%)$ and $\left[\left(\mathrm{Cp}^{*} \mathrm{~W}\right)_{2}(\mu-\mathrm{Se})_{2}(\mu-\mathrm{SePh})_{2}\right], 3 \quad(0.024 \mathrm{~g}$, $10 \%)$ as blue and purple solids respectively.

Note that complexes $\mathbf{2}$ and $\mathbf{3}$ have been isolated along with the metallaborane $\left[(\mathrm{Cp} * \mathrm{Mo})_{2} \mathrm{~B}_{5} \mathrm{H}_{9}\right]$, $\mathbf{4 a}^{32 \mathrm{a}, \mathrm{b}, \mathrm{d}}(0.008 \mathrm{~g}, 6 \%)$ and $\left[(\mathrm{Cp} * \mathrm{~W})_{2} \mathrm{~B}_{5} \mathrm{H}_{9}\right], \mathbf{4 b}^{32 \mathrm{c}, \mathrm{d}}$ (0.012 g, 8\%).

1: $\mathrm{MS}\left(\mathrm{ESI}^{+}\right): \mathrm{m} / z$ calculated for $\mathrm{C}_{32} \mathrm{H}_{41} \mathrm{Cr}_{2} \mathrm{Se}_{4}$ : $844.4[\mathrm{M}-2 \mathrm{Se}+\mathrm{H}]^{+}$, found: 844.7; ${ }^{1} \mathrm{H} \mathrm{NMR}$ $\left(500 \mathrm{MHz}, \mathrm{C}_{6} \mathrm{D}_{6}, 22{ }^{\circ} \mathrm{C}\right): \delta=7.52-6.87\left(\mathrm{~m}, \mathrm{C}_{6} \mathrm{H}_{5}\right)$, $2.12\left(\mathrm{~s}, 30 \mathrm{H}, \mathrm{Cp}^{*}\right)$.

2: HR-MS $\left(\right.$ ESI $\left.^{+}\right): \mathrm{m} / z$ calcd for $\mathrm{C}_{32} \mathrm{H}_{40} \mathrm{Mo}_{2} \mathrm{KSe}_{4}$ : 978.7536 $[\mathrm{M}+\mathrm{K}]^{+}$, found: 978.7532; ${ }^{1} \mathrm{H} \mathrm{NMR}$ $\left(500 \mathrm{MHz}, \mathrm{CDCl}_{3}, 22^{\circ} \mathrm{C}\right): \delta=7.01-6.89\left(\mathrm{~m}, \mathrm{C}_{6} \mathrm{H}_{5}\right)$, 2.20 (s, 30H, Cp*); ${ }^{13} \mathrm{C}\left\{{ }^{1} \mathrm{H}\right\}$ NMR (125 MHz, $\mathrm{CDCl}_{3}$, 
$\left.22{ }^{\circ} \mathrm{C}\right): \delta=135.8-126.5\left(\mathrm{C}_{6} \mathrm{H}_{5}\right), 110.8\left(\mathrm{~s}, C_{5} \mathrm{Me}_{5}\right)$, $14.9 \mathrm{ppm}\left(\mathrm{s}, \mathrm{C}_{5} M e_{5}\right)$.

3: $\mathrm{MS}\left(\mathrm{ESI}^{+}\right): \mathrm{m} / \mathrm{z}$ calcd for $\mathrm{C}_{32} \mathrm{H}_{40} \mathrm{~W}_{2} \mathrm{Se}_{4}: 1111.8$ $[\mathrm{M}]^{+}$, found: $1111.8 ;{ }^{1} \mathrm{H} \mathrm{NMR}\left(500 \mathrm{MHz}, \mathrm{CDCl}_{3}\right.$, $\left.22{ }^{\circ} \mathrm{C}\right): \delta=6.99-6.89\left(\mathrm{~m}, \mathrm{C}_{6} \mathrm{H}_{5}\right), 2.53$ (s, 30H, Cp*); ${ }^{13} \mathrm{C}\left\{{ }^{1} \mathrm{H}\right\} \quad$ NMR $\quad\left(125 \mathrm{MHz}, \quad \mathrm{CDCl}_{3}, \quad 22{ }^{\circ} \mathrm{C}\right)$ : $\delta=135.1-125.4\left(\mathrm{~s}, \mathrm{C}_{6} \mathrm{H}_{5}\right), 107.1\left(\mathrm{~s}, C_{5} \mathrm{Me}_{5}\right), 14.9 \mathrm{ppm}(\mathrm{s}$, $\left.\mathrm{C}_{5} M e_{5}\right)$.

\subsection{Synthesis of 5-7}

A suspension of $\left[\mathrm{Cp}^{*} \mathrm{NbCl}_{4}\right](0.5 \mathrm{~g}, 1.3 \mathrm{mmol})$ in $10 \mathrm{~mL}$ toluene at $-78{ }^{\circ} \mathrm{C}$ was charged dropwise with a freshly prepared solution of $\mathrm{Li}\left[\mathrm{BH}_{3}(\mathrm{SPh})\right],(5.4 \mathrm{mmol})$ over $15 \mathrm{~min}$. The $\mathrm{Li}\left[\mathrm{BH}_{3}(\mathrm{SPh})\right]$ solution was prepared from the reaction of $\left[\mathrm{Ph}_{2} \mathrm{~S}_{2}\right]$ with $\mathrm{LiBH}_{4}$.THF at ice cooled temperature. The reaction mixture was warmed to room temperature over 1 hour and then heated to $90{ }^{\circ} \mathrm{C}$ for $48 \mathrm{~h}$. The solvent was dried and the residue was extracted in $n$-hexane and passed through Celite. After removal of the solvent, the residue was subjected to chromatographic work-up by using TLC plates ( $n$ hexane $\left./ \mathrm{CH}_{2} \mathrm{Cl}_{2}, \quad 70: 30 \mathrm{v} / \mathrm{v}\right)$ to yield complex $\left[(\mathrm{Cp} * \mathrm{Nb})_{2}\left(\mu-\mathrm{S}_{2}\right)_{2}\right], 5(0.024 \mathrm{~g}, 6 \%)$ as orange solid. Under similar reaction conditions the treatment with $\mathrm{Li}\left[\mathrm{BH}_{3}(\mathrm{SePh})\right], \quad(5.4 \mathrm{mmol})$ yielded $\quad\left[(\mathrm{Cp} * \mathrm{Nb})_{2}(\mu-\right.$ $\left.\mathrm{Se}_{2}\right)_{2}$ ], $6(0.047 \mathrm{~g}, 9 \%)$ as purple solid.

Note that the complexes 5 and $\mathbf{6}$ have been isolated along with $\left[(\mathrm{Cp} * \mathrm{Nb})_{2}\left(\mathrm{~B}_{2} \mathrm{H}_{6}\right)_{2}\right], 7^{33}(0.027 \mathrm{~g}, 8 \%)$ and several air and moisture sensitive complexes which we were unable to isolate.

5: HR-MS $\left(\mathrm{ESI}^{+}\right)$: $\mathrm{m} / \mathrm{z}$ calcd. for $\mathrm{C}_{20} \mathrm{H}_{31} \mathrm{Nb}_{2} \mathrm{~S}_{4}$ : $584.9436[\mathrm{M}+\mathrm{H}]^{+}$, found 584.9451; ${ }^{1} \mathrm{H}$ NMR $\left(500 \mathrm{MHz}, \mathrm{CDCl}_{3}, 22{ }^{\circ} \mathrm{C}\right): \delta=2.07$ (s, 30H, Cp*); ${ }^{13} \mathrm{C}\left\{{ }^{1} \mathrm{H}\right\}$ NMR $\left(125 \mathrm{MHz}, \mathrm{CDCl}_{3}, 22{ }^{\circ} \mathrm{C}\right): \delta=111.0$, (s, $\left.C_{5} \mathrm{Me}_{5}\right), 11.8 \mathrm{ppm}\left(\mathrm{s}, \mathrm{C}_{5} \mathrm{Me}_{5}\right)$.

6: HR-MS $\left(\mathrm{ESI}^{+}\right): \mathrm{m} / \mathrm{z}$ calcd for $\mathrm{C}_{20} \mathrm{H}_{30} \mathrm{KNb}_{2} \mathrm{Se}_{4}$ : 814.6773 $[\mathrm{M}+\mathrm{H}]^{+}$, found 814.6790; ${ }^{1} \mathrm{H}$ NMR $\left(500 \mathrm{MHz}, \mathrm{CDCl}_{3}, 22{ }^{\circ} \mathrm{C}\right): \delta=2.26\left(\mathrm{~s}, 30 \mathrm{H}, \mathrm{Cp}^{*}\right)$, ${ }^{13} \mathrm{C}\left\{{ }^{1} \mathrm{H}\right\}$ NMR $\left(125 \mathrm{MHz}, \mathrm{CDCl}_{3}, 22{ }^{\circ} \mathrm{C}\right): \delta=111.3$ $\left(\mathrm{s}, \mathrm{C}_{5} \mathrm{Me}_{5}\right), 13.3 \mathrm{ppm}\left(\mathrm{s}, \mathrm{C}_{5} \mathrm{Me}_{5}\right)$.

\section{$2.4 X$-ray structure determination}

The crystal data for $\mathbf{1 , 3}, \mathbf{5}$ and $\mathbf{6}$ were collected and integrated using a Bruker kappa apex II CCD diffractometer with graphite-monochromated $\mathrm{MoK} \alpha$ $(\lambda=0.71073 \AA)$ radiation at $296 \mathrm{~K}$. The structures were solved by heavy atom methods using SHELXS2016 and refined by using SHELXL-2016/SHELXL2017 (Sheldrick, G.M., University of Göttingen) (Table 1). ${ }^{34}$

\subsection{Computational details}

The quantum chemical calculations were performed on the simplified model complexes $\mathbf{1}^{\prime}, \mathbf{2}^{\prime}, \mathbf{3}^{\prime}, \mathbf{5}^{\prime}$ and $\mathbf{6}^{\prime}(\mathrm{Cp}$ analogues of $\mathbf{1}, \mathbf{2}, \mathbf{3}, \mathbf{5}$ and $\mathbf{6}$ ) and I-IV using the Gaussian 09 program package. ${ }^{35}$ Geometry optimization was conducted in the gaseous state (no solvent effect) without any symmetry constraints using the BP86 $6^{36}$ functional paired with a mixed basis set: Stuttgart/Dresden double- $\zeta$ (SDD) effective core potentials $(\mathrm{ECPs})^{37}$ for $\mathrm{Nb}$, Ta, Mo and $\mathrm{W} ; 6-31 \mathrm{~g}^{*}$ basis set for the other atoms. The optimized geometries were characterized as true minima by using analytical frequency calculations. Wiberg bond indices (WBIs) ${ }^{38}$ were obtained from a natural bond orbital (NBO) $)^{39}$ analysis. All the optimized structures and orbital graphics were generated by using the Chemcraft. ${ }^{40}$

\section{Results and Discussion}

\subsection{Reactivity of $\left[\mathrm{Cp}^{*} \mathrm{CrCl}\right]_{2}$ with $\mathrm{Li}\left[\mathrm{BH}_{3}(\mathrm{SePh})\right]$}

From our recent studies, it was proved that $\mathrm{Li}\left[\mathrm{BH}_{3}(-\right.$ $\mathrm{EPh})](\mathrm{E}=\mathrm{S}, \mathrm{Se})$ is a potential reagent for the synthesis of metallachalcogenoboranes. ${ }^{25-27}$ Among group 6 metals, the examples of chromium heteroborane complexes are very few. ${ }^{41}$ In this context, we have performed the room temperature reaction of $\left[\mathrm{Cp}^{*} \mathrm{CrCl}\right]_{2}$ with two equivalents of $\mathrm{Li}\left[\mathrm{BH}_{3}(\mathrm{SePh})\right]$ with an aim to synthesize dichromaselenaboranes. Surprisingly, the reaction led to the formation of a unique complex, $\left[\left(\mathrm{Cp}^{*} \mathrm{Cr}\right)_{2}\left(\mu-\mathrm{Se}_{2} \mathrm{SePh}\right)_{2}\right], \mathbf{1}$ (Scheme 1). Complex $\mathbf{1}$ was isolated as violet crystals, which were characterized by ${ }^{1} \mathrm{H}$, mass spectrometry and by single-crystal X-ray crystallography. The ${ }^{1} \mathrm{H}$ NMR spectrum showed the presence of $\mathrm{Cp}^{*}$ and phenyl protons. The ${ }^{11} \mathrm{~B}$ NMR showed no ${ }^{11} \mathrm{~B}$ chemical shift confirming the absence of boron in 1. Although the ${ }^{11} \mathrm{~B}$ NMR of the reaction mixture indicates formation of several metallaborane species, due to low yield and sensitive nature, their isolation could not be carried out. The mass spectrometric analysis of $\mathbf{1}$ shows molecular ion peaks at $\mathrm{m} /$ $z 844.7$ which is equivalent to the mass of 1 minus two Se atoms. The complete structure of $\mathbf{1}$ is identified by single-crystal $\mathrm{X}$-ray crystallography as shown in Figure 1.

Single crystals of $\mathbf{1}$ were obtained by slow diffusion of hexanes into a dichloromethane solution. The X-ray diffraction analysis confirmed that $\mathbf{1}$ is a chalcogenbridged bimetallic $\mathrm{Cr}$ complex with two $\left[\mathrm{Se}_{2} \mathrm{SePh}\right]^{3-}$ units having close similarity with lanthanide-chalcogen cluster, $\left[(\text { pyridine })_{8} \mathrm{Yb}_{4}(\mathrm{SeSe})_{2}(\mathrm{Se})_{2}\left(\mu_{2}-\mathrm{SPh}\right)_{2}(\mathrm{SPh})_{2}\right] .{ }^{42}$ 


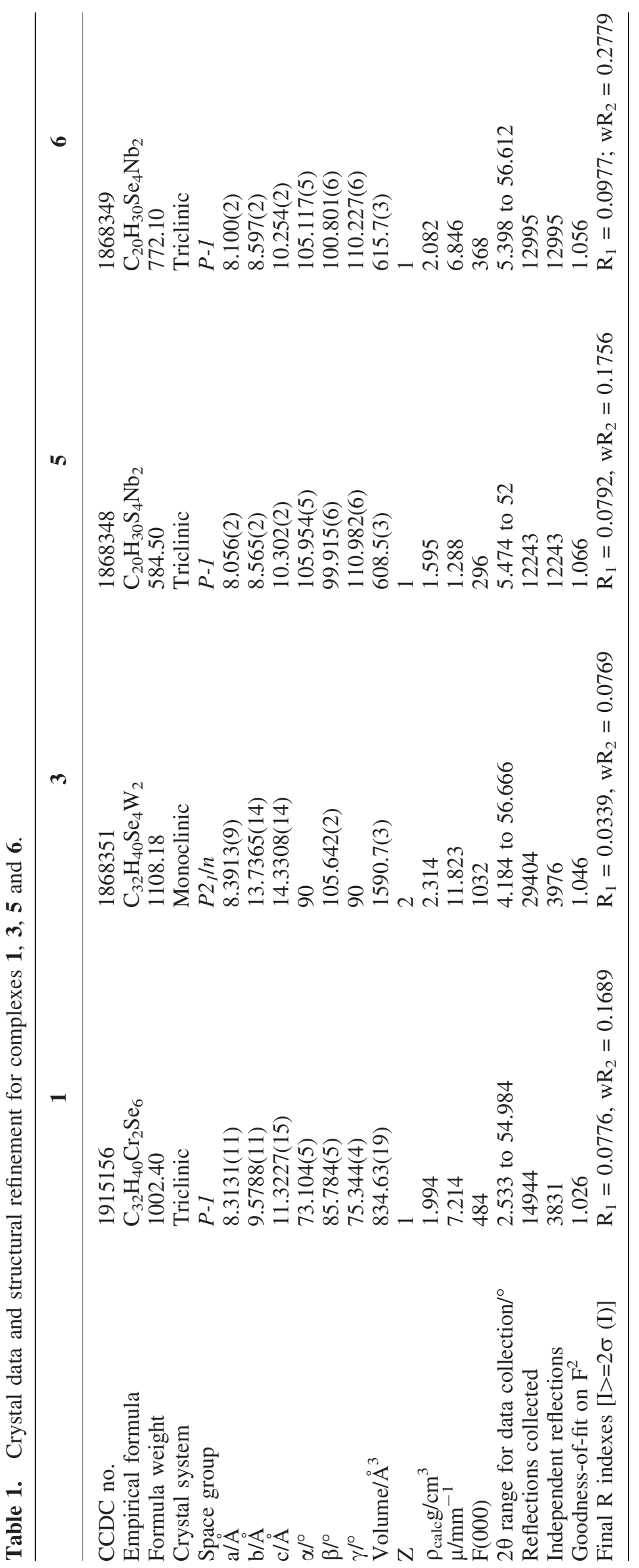




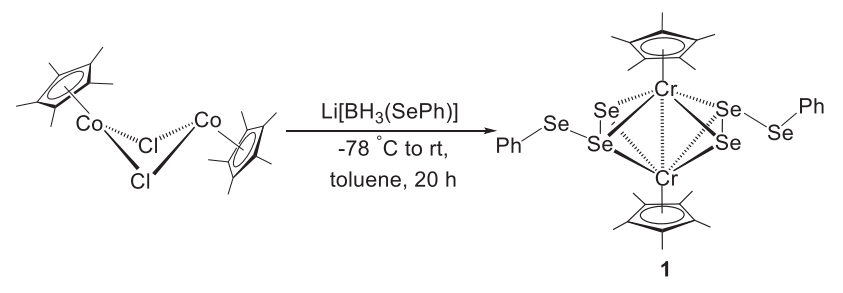

Scheme 1. Synthesis of $\mathbf{1}$.

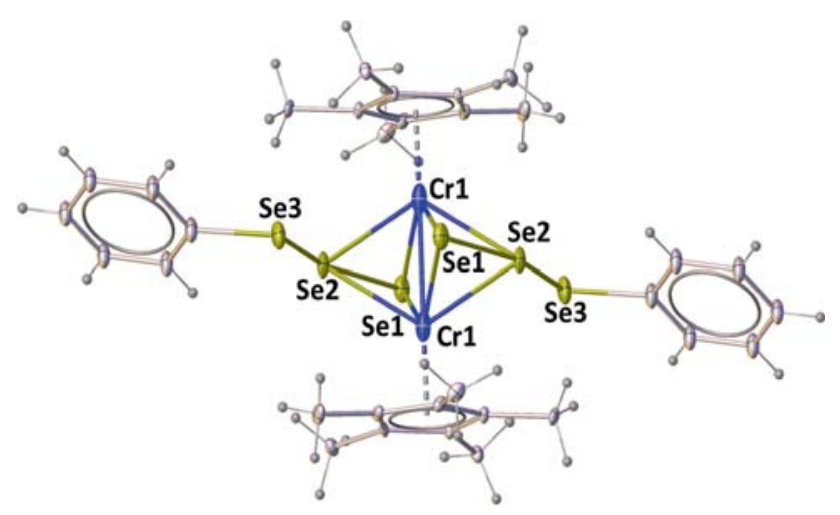

Figure 1. Molecular structure and labelling diagram for $\mathbf{1}$. Selected bond distances $(\AA)$ and angle $\left({ }^{\circ}\right)$ : $\mathrm{Cr} 1-\mathrm{Cr} 1$ 2.588(2), Se1-Se2 2.6794(10), Se2-Se3 2.5065(11), Cr1Se1 2.4211(13); Se1-Cr1-Se2 80.63(4), Cr1-Se2-Se3 111.30(4), Se1-Cr1-Cr1 57.76(5), Se2-Cr1-Cr1 58.40(4).

Although triple bridged chalcogen stabilized binuclear complexes of chromium are known in literature, ${ }^{43}$ quadruple bridged heavier chalcogen rich binuclear complexes of chromium like $\mathbf{1}$ are sporadic. The molecular structure of $\mathbf{1}$ is symmetrical and has a direct Cr-Cr bond (2.588(2) $\AA$ ), which is significantly shorter as compared to normal $\mathrm{Cr}-\mathrm{Cr}$ single bond found in related binuclear complexes $[2.950(2) \AA$ for $[\mathrm{CpCr}(\mu$ $\mathrm{SPh})(\mathrm{NO})]_{2},{ }^{44}$ and $2.906(3) \AA$ for $\left[\mathrm{Cp}_{2} \mathrm{Cr}_{2}(\mathrm{NO})_{2}(\mu-\right.$ $\left.\left.\mathrm{SCMe}_{3}\right)\left(\mu-\mathrm{S}-\mathrm{SCMe}_{3}\right)\right]{ }^{45}$ Based on the $\mathrm{Cr}-\mathrm{Cr}$ bond distance, we assume that there lies a double bond character. The presence of $\mathrm{Cr}-\mathrm{Cr}$ double bond has been earlier identified in $\left[\{\mathrm{CpCr}(\mu-\mathrm{SPh})\}_{2} \mathrm{~S}\right]$, a well-known binuclear chromium chalcogen complex that exhibited antiferromagnetic properties. ${ }^{45 \mathrm{~b}}$ The core geometry of $\mathrm{Cr}_{2} \mathrm{Se}_{4}$ can also be considered as fusion of two tetrahedral $\left(\mathrm{Cr}_{2} \mathrm{Se}_{2}\right)$ through $\mathrm{Cr}-\mathrm{Cr}$ edge. One of the interesting features of $\mathbf{1}$ is that two $\mathrm{SeSe}_{2} \mathrm{Ph}$ units adopt perfectly symmetric disposition perpendicular to the metal-metal axis and parallel to $\mathrm{Cp}^{*}$ planes. The average bond angle for $\mathrm{Cr} 1-\mathrm{Se} 2-\mathrm{Se} 3$ is $110.45^{\circ}$ and for $\mathrm{Cr} 1-$ $\mathrm{Se} 1 / 2-\mathrm{Cr} 1$ is $64.05^{\circ}$. There are two different $\mathrm{Se}-\mathrm{Se}$ bonds present in $\left[\mu_{2}-\eta_{2}-\eta_{2}-\mathrm{SeSeSePh}\right]^{3-}, \operatorname{Se}(1)-\mathrm{Se}(2)$ $(2.6794(10) \AA)$ and $\operatorname{Se}(3)-\operatorname{Se}(2) \quad(2.5065(11) \AA)$. Although they are considerably longer than the usual
Se-Se single bond, ${ }^{47}$ they are comparable to those of [(pyridine $\left.)_{8} \mathrm{Yb}_{4}(\mathrm{SeSe})_{2}(\mathrm{Se})_{2}\left(\mu_{2}-\mathrm{SPh}\right)_{2}(\mathrm{SPh})_{2}\right] .{ }^{42} \mathrm{The} \mathrm{Cr}$ metal centre follows $18 \mathrm{e}$ rule in $\mathbf{1}$ (6e from the metal, $5 \mathrm{e}$ from $\mathrm{Cp}^{*}, 1$ each from the Se atom connected to $\mathrm{SePh}$ and 3 from the other $\mathrm{Se}$ atoms). Moreover, the oxidation state of $\mathrm{Cr}$ is +4 due to the presence of anionic $\mathrm{Cp}^{*^{-}}$and $\left[\mathrm{Se}_{2} \mathrm{SePh}\right]^{3-}$ ligands, making it as a $\mathrm{d}^{2}-$ $\mathrm{d}^{2}$ homo-bimetallic complex.

\subsection{Reactivity of $\left[C p^{*} \mathrm{MCl}_{4}\right](M=\mathrm{Mo}, \mathrm{W})$ with $\mathrm{Li}\left[\mathrm{BH}_{3}(\mathrm{SePh})\right]$}

In an attempt to isolate analogous complex of $\mathbf{1}$ composed of heavier group 6 metals we have carried out the reaction of $\left[\mathrm{Cp} * \mathrm{MCl}_{4}\right](\mathrm{M}=\mathrm{Mo}$ and $\mathrm{W})$ with $\mathrm{Li}\left[\mathrm{BH}_{3}(\mathrm{SePh})\right]$. Unexpectedly, the reaction did not form analogue of $\mathbf{1}$, instead it led to the formation of similar kind of binuclear chalcogen clusters $\left[(\mathrm{Cp} * \mathrm{Mo})_{2}(\mu-\mathrm{Se})_{2}(\mu-\mathrm{SePh})_{2}\right], \quad 2$ and $\left[(\mathrm{Cp} * \mathrm{~W})_{2}(\mu-\right.$ $\left.\mathrm{Se})_{2}(\mu-\mathrm{SePh})_{2}\right], 3$ (Scheme 2). Although chalcogen stabilized binuclear complexes of molybdenum are well known, ${ }^{18 a}$ structurally characterized diselenolato complexes of tungsten are scarce. In parallel to the formation of $\mathbf{2}$ and $\mathbf{3}$, the reaction also yielded known $\left[(\mathrm{Cp} * \mathrm{M})_{2} \mathrm{~B}_{5} \mathrm{H}_{9}\right], \mathbf{4 a - b}(\mathbf{4 a}: \mathrm{M}=\mathrm{Mo} ; \mathbf{4 b}: \mathrm{M}=\mathrm{W}){ }^{32}$ The ${ }^{1} \mathrm{H}$ NMR spectra of $\mathbf{2}$ and $\mathbf{3}$ show single peak at $\delta=2.20$ and $2.53 \mathrm{ppm}$ respectively for the $\mathrm{Cp}^{*}$ ligand. The ${ }^{13} \mathrm{C}$ NMR spectra also furnishes the presence of one kind of $\mathrm{Cp}^{*}$ ligand for these complexes. Based on the spectroscopic data along with mass spectrometric analysis, complex 2 was characterized as $\left[\left(\mathrm{Cp}^{*} \mathrm{Mo}\right)_{2}(\mu-\mathrm{Se})_{2}(\mu-\mathrm{SePh})_{2}\right]$, in comparison with earlier reported $\left[(\mathrm{CpMo})_{2}(\mu-\mathrm{Se})_{2}(\mu-\mathrm{SePh})_{2}\right]{ }^{46}$ On the other hand, complex $\mathbf{3}$ shows molecular ion peak at $\mathrm{m} / \mathrm{z}=1111.8$ that indicates the formation of $\mathrm{C}_{32} \mathrm{H}_{40} \mathrm{~W}_{2} \mathrm{Se}_{4}$.

The molecular structure of $\mathbf{3}$ has been unequivocally determined by X-ray diffraction analysis (Figure 2). The crystal structure of $\mathbf{3}$ envisions the molecule as a chalcogen-bridged binuclear complex stabilized in the coordination sphere of two $\mu$-selenido and $\mu$ -

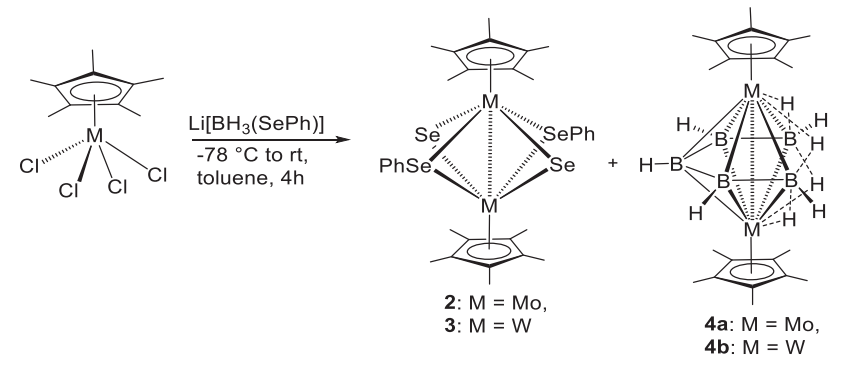

Scheme 2. Synthesis of binuclear complexes 2-4. 


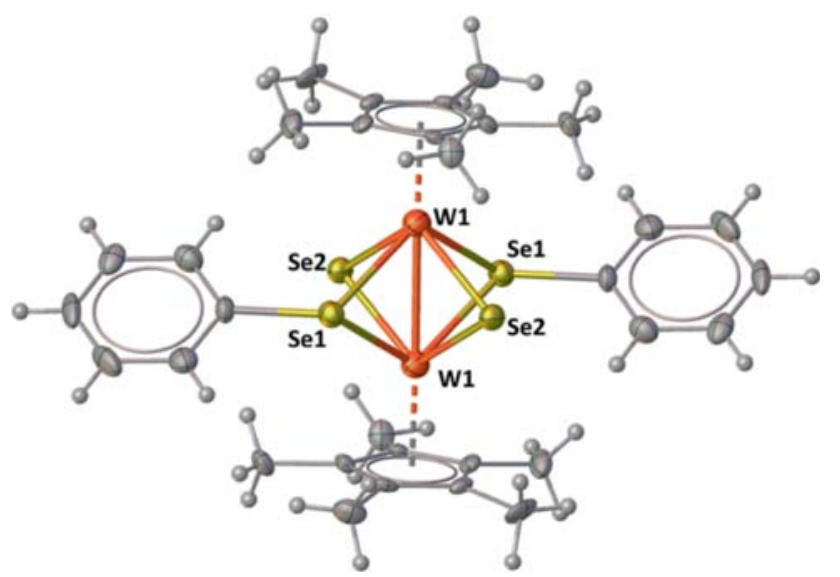

Figure 2. Molecular structure and labelling diagram of $\left[(\mathrm{Cp} * \mathrm{~W})_{2}(\mu \text {-Se })_{2}(\mu-\mathrm{SePh})_{2}\right], 3$. Selected bond distances $(\AA)$ and angle $\left({ }^{\circ}\right)$ : W1-W1 2.6595(5), W1-Se2 2.4893(7), W1Se1 2.5850(7); W1-Se1-W1 61.513(17), W1-Se2-W1 64.531(18) Se2-W1-Se1 78.08(2), Se1-W1-Se1 118.488(17).

selenolato ligands. The molecule possesses a crystallographic inversion symmetry consists of a linear $\mathrm{Cp}^{*}$ $\mathrm{W}$-W-Cp* unit in which the $\pi$-bonded $\mathrm{Cp}^{*}$ ligands lie perpendicular to the $\mathrm{W}-\mathrm{W}$ bond. The $\mathrm{W}-\mathrm{W}$ bond length of 2.6595(5) $\AA$ is significantly shorter than in $\left[\mathrm{W}_{2}(\mathrm{CO})_{4}(\mu-\mathrm{SePh})_{6}\right],{ }^{47}\left[\mathrm{~W}_{2}\left(\mu-\mathrm{S}_{2}\right)_{2} \mathrm{Cl}_{6}\left(\mathrm{SeCl}_{2}\right)_{2}\right]^{48}$ and $\left[\mathrm{W}_{2}\left(\mu-\mathrm{S}_{2}\right)_{2}\left(\mathrm{~S}_{2} \mathrm{CNR}_{2}\right)_{4}\right]^{2+}{ }^{49}$ However, it is found to be longer than those observed in $\left[\mathrm{Cp}^{*} \mathrm{WCl}_{2}(\mu-\mathrm{H})\right]_{2}{ }^{50}$ and dithiolato-bridged complex of tungsten, $\left[(\mathrm{Cp} * \mathrm{~W})_{2}(\mu-\right.$ $\left.\mathrm{S})_{2}\left(\mu-\eta^{2}-\mathrm{S}_{2} \mathrm{CH}_{2}\right)\right] .{ }^{51}$ The short $\mathrm{W}-\mathrm{W}$ bond distance indicates a double bond interaction similar to Mo-Mo double bond $(2.653(2) \AA)$ identified in $\left[(\mathrm{CpMo})_{2}(\mu\right.$ $\left.\mathrm{Se})_{2}(\mu-\mathrm{SePh})_{2}\right] .{ }^{46}$ The short $\mathrm{W}-\mathrm{W}$ distance is compatible with sharp acute $\mathrm{W}-\mathrm{S}-\mathrm{W}$ bite angles in the range of $61.79-64.53^{\circ}$. The $\mathrm{W}-\mathrm{W}$ double bond is bridged across by two alternate pairs of monoselenido and phenylselenolato ligands. The $\mathrm{W}$ atoms lie in plane with both the Sel (phenylselenolato bridge) atoms on one side and both $\mathrm{Se} 2$ (selenido bridge) on the other side with an interplanar angle of $84.36^{\circ}$. Short contacts between the Se atoms, Se1-Se2 (2.917 (1) and 3.218 (1) $\AA$ ) are observed which are in between the sum of the van der Waals radius of two Se atoms $(3.8 \AA)$ indicating the existence of nonbonding interactions between the bridging Se atoms in $\mathbf{3}$. The $\mathrm{W}$-Se bond lengths differ to a significant extent that may be due to the coordination of bridging ( $\mu$-Se) and $(\mu-\mathrm{SePh})$ ligands to the metal centers. In case of bridging $\mu$-selenido ligands, the $\mathrm{W}$-Se bond distances lie in between 2.489 and $2.492 \AA$, comparable to $\mathrm{W}$-Se distances observed in $\left[(\mathrm{CpW})_{2} \mathrm{O}_{2}(\mu-\mathrm{Se})_{2}\right] .{ }^{52}$ However, the bond length increases when the metal centers are coordinated to $\mu$-selenolato ligands that can be compared with $\left[\mathrm{W}_{2}(\mathrm{CO})_{4}(\mu-\mathrm{SePh})_{4}(\mathrm{SePh})_{2}\right] .{ }^{47}$ All the $\mathrm{W}-\mathrm{Se}$ bonds are much shorter than the sum of the covalent radii of $\mathrm{W}$ and $\mathrm{Se}(2.82 \AA)$ indicating a stronger bonding interaction.

The crystal structure further revealed that the complex $\mathbf{3}$ is a trans/anti isomer (Figure 2) with the similar ligands are trans to each other and the $\mathrm{Ph}$ group is in the anti-orientation with respect to the $\mathrm{W}_{2} \mathrm{Se}_{2}$ (selenato) ring. The four-bridged atoms in the complex constitute a plane, which is parallel to the two substituted cyclopentadienyl ring planes and bisects the $\mathrm{W}-\mathrm{W}$ vector perpendicularly. The molecule can also be visualized as a $\left[\mathrm{W}_{2} \mathrm{Se}_{4}\right]$ paddle wheel-like complex. Considering the two connected $(\mu-\mathrm{Se})$ and $(\mu-\mathrm{SePh})$ ligands as two and three electron donors, $\mathbf{3}$ displays a chalcogen-bridged 36-electron bimetallic-selenium complex (18e to each metal) probably with the existence of the W-W double bond. On the other hand, taking the $\mathrm{Cp}^{*}$ ligands as monoanions and two diverse selenium ligands as dianions $\left[\mathrm{Se}^{2-}\right.$ and $\left.(\mathrm{SePh})^{-}\right]$, each of the $\mathrm{W}$ atoms possess a $+\mathrm{IV}$ oxidation state with $\mathrm{d}^{2}$ configuration similar to complex $\mathbf{1}$.

\subsection{Reactivity of $\mathrm{Cp}^{*} \mathrm{NbCl}_{4}$ with $\mathrm{Li}_{[}\left[\mathrm{BH}_{3}(\mathrm{EPh})\right]$ $(E=S$ and $S e)$}

To extend the same approach to synthesize group 5 chalcogen complexes similar to $\mathbf{1}-\mathbf{3}$, we have carried out the reactivity of $\left[\mathrm{Cp}^{*} \mathrm{NbCl}_{4}\right]$ with $\mathrm{Li}\left[\mathrm{BH}_{3}(\mathrm{EPh})\right]$ $(\mathrm{E}=\mathrm{S}$ and $\mathrm{Se})$. Thermolysis of $\left[\mathrm{Cp}^{*} \mathrm{NbCl}_{4}\right]$ with $\mathrm{Li}\left[\mathrm{BH}_{3}(\mathrm{EPh})\right]$ at $90{ }^{\circ} \mathrm{C}$ afforded $\left[\left(\mathrm{Cp}^{*} \mathrm{Nb}\right)_{2}\left(\mu-\mathrm{E}_{2}\right)_{2}\right], 5$ and $6(5: \mathrm{E}=\mathrm{S}$ and 6: $\mathrm{E}=\mathrm{Se})($ Scheme 3) in 6-9\% yields along with the formation of known $\left[(\mathrm{Cp} * \mathrm{Nb})_{2}\left(\mathrm{~B}_{2} \mathrm{H}_{6}\right)_{2}\right],{ }^{33}$ 7. It is important to mention that these reactions also yielded several air and moisture sensitive complexes which could not be isolated from the reaction mixture. Complexes $\mathbf{5}$ and $\mathbf{6}$ were characterized by spectroscopic as well as crystallographic analysis. The ${ }^{1} \mathrm{H}$ NMR spectra of both $\mathbf{5}$ and $\mathbf{6}$ show single peak at $\delta=2.07$ and $2.26 \mathrm{ppm}$ for $\mathrm{Cp}^{*}$ ligand respectively, which in turn predicts the static symmetric structures. The ${ }^{13} \mathrm{C}$ NMR also supports the presence of one kind of $\mathrm{Cp}^{*}$ ligand for each of these

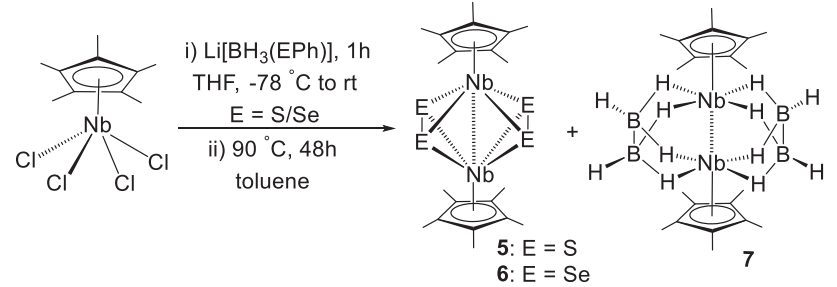

Scheme 3. Synthesis of binuclear complexes 5-7. 


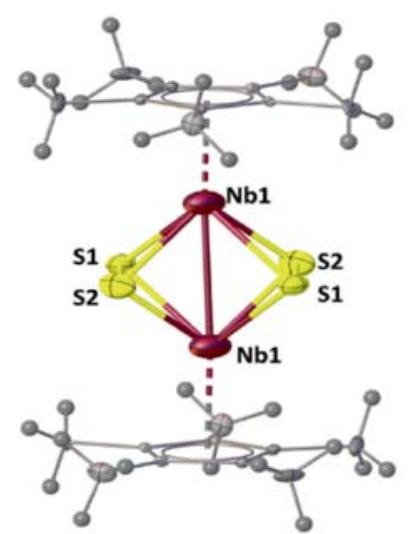

(a)

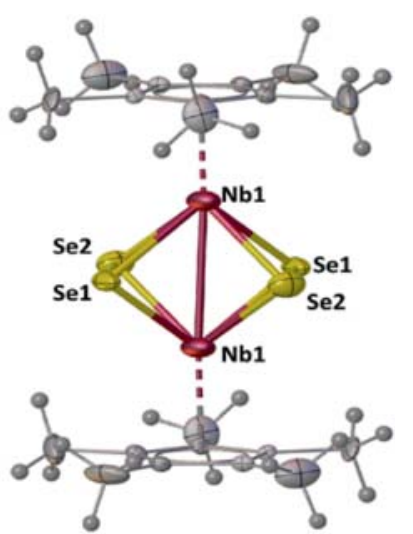

(b)
Figure 3. Molecular structure and labelling diagrams for 5 and 6. Selected bond distances $(\AA)$ and angle $\left(^{\circ}\right)$ : (a) 5: S1-Nb1 2.481(14), S2-Nb1 2.304(17), S1-S2 2.39(3); S2$\mathrm{S} 1-\mathrm{Nb} 1$ 56.5(6), Nb1-S2-S1 63.8(5). (b) 6: Nb1-Se2 2.439(5), Se1-Se2 2.364(10); Se2-Se1-Nb1 59.97(19), Se1-Se2-Nb1 63.0(2).

complexes. In addition, the peak in the mass spectra at $\mathrm{m} / \mathrm{z}=584.9451$ and 814.6790 for $\mathbf{5}$ and $\mathbf{6}$ respectively is consistent with their composition.

To authorize the spectroscopic assignments and to elucidate the solid-state X-ray structures of $\mathbf{5}$ and $\mathbf{6}$, $\mathrm{X}$-ray diffraction structure analyses were performed. Single crystals suitable for $\mathrm{X}$-ray diffraction studies of 5 and $\mathbf{6}$ were obtained from a hexane/ $\mathrm{CH}_{2} \mathrm{Cl}_{2}$ solution at $-10{ }^{\circ} \mathrm{C}$ that allowed structural interpretation. The molecular structures of these complexes shown in Figure $3 \mathrm{a}-\mathrm{b}$, can be depicted as chalcogen-bridged binuclear complexes where each metal is coordinated to a $\eta^{5}-\mathrm{Cp}^{*}$ ligand and four $\mu$ bridging chalcogen atoms (S/Se). Interestingly complexes 5 and $\mathbf{6}$ possess the central $\left[\mathrm{Nb}_{2}\left(\mu-\mathrm{E}_{2}\right)_{2}\right]$ $(\mathrm{E}=\mathrm{S}, \mathrm{Se})$ core, where the coordination between disulfur and diselenide ligands with the metal centers provides $\eta^{2}-\eta^{2}-\mu_{2}$ coordination of acetylene type. Similar kind of coordination modes have been well explicated in $\left.\left[\mathrm{Nb}_{2}\left(\mu-\mathrm{S}_{2}\right)_{2}(\mathrm{NCS})_{8}\right]^{4-}\right\}^{19 \mathrm{a}}$ and $\left.\left[\mathrm{Nb}_{2}\left(\mu-\mathrm{S}_{2}\right)_{2}\left(\mathrm{H}_{2} \mathrm{O}\right)_{8}\right]^{4+}\right]^{19 \mathrm{a}}$ complexes.
The calculated $\mathrm{Nb}-\mathrm{Nb}$ bond distance of $2.780 \AA$ in $\mathbf{5}$ is found to be considerably shorter than $\left[\mathrm{Nb}_{2}\left(\mu-\mathrm{S}_{2}\right)_{2}\right.$ $\left.(\mathrm{NCS})_{8}\right]^{4-19 \mathrm{a}}(2.913(2) \AA), \quad\left[\mathrm{Nb}_{2}\left(\mu-\mathrm{S}_{2}\right)_{2}\left(\mathrm{H}_{2} \mathrm{O}\right)_{8}\right]^{4+19 \mathrm{a}}$ $(2.898(11) \AA)$ and $\left[\mathrm{Nb}_{2} \mathrm{~S}_{4}\left(\mathrm{Et}_{2} \mathrm{NCS}_{2}\right)_{4}\right](2.892(9) \AA) .{ }^{53}$ The $\mathrm{Nb}-\mathrm{Nb}$ bond length gets elongated when $\mathrm{S}$ is substituted by $\mathrm{Se}$ in $\mathbf{5}$. Nevertheless, the calculated $\mathrm{Nb}-\mathrm{Nb}$ distance of $2.805 \AA$ in $\mathbf{6}$ is considerably shorter as compared to the $\mathrm{Nb}-\mathrm{Nb}$ distances having $\mathrm{Nb}_{2} \mathrm{Se}_{4}$ core in $\left[\mathrm{Nb}_{2} \mathrm{Se}_{4}\left(\mathrm{Et}_{2} \mathrm{NCS}_{2}\right)_{4}\right]^{54}$ and $\left[\mathrm{Nb}_{2} \mathrm{Se}_{4}\right]\left[\mathrm{Te}_{2} \mathrm{I}_{6}\right]_{2} .{ }^{54}$ In that context, some of the typical structural parameters of $\mathbf{5}$ and $\mathbf{6}$ have been compared with reported binuclear complexes owning similar structural core (Table 2), that shows significant difference in bond distances of $\mathbf{5}$ and $\mathbf{6}$ in presence of cyclopentadienyl ligands. The solid-state X-ray structures of $\mathbf{5}$ and $\mathbf{6}$ can also be represented as a paddle-wheel like complex comprising of $\left[\mathrm{Nb}_{2} \mathrm{~S}_{4}\right]$ and $\left[\mathrm{Nb}_{2} \mathrm{Se}_{4}\right]$ in which all the four sulphur and the selenium atoms of the paddle are linked to the $\mathrm{Nb}$ metals. ${ }^{55}$

\subsection{Electronic structure analysis of complexes $\mathbf{1}$ - 3,5 and 6}

Even though many structurally characterized metalchalcogen complexes, similar to 1-3, 5 and $\mathbf{6}$ are known, theoretical aspects of these complexes have not been explored to a significant extent to understand their bonding and electronic structure. Hence, in order to illustrate the electronic structure and bonding of 1-3 and 5-6, the DFT studies were performed. The Cp analogues, $\mathbf{1}^{\prime}-\mathbf{3}^{\prime}, \mathbf{5}^{\prime}$ and $\mathbf{6}^{\prime}$ are optimized with BP86/ SDD, 6-31 g* level of theory. The structure of $\mathbf{1}$ is slightly different from $\mathbf{2}$ and $\mathbf{3}$ even though the metals belong to same group. The bond parameters of $\mathbf{2}$ and $\mathbf{3}$ are in good agreement with the theoretical values (Table S1, Supplementary Information) whereas $\mathbf{1}$ is in moderate agreement. The $\mathrm{M}-\mathrm{M}$ bond distance is slightly shortened and $\mathrm{Se} 1-\mathrm{Se} 2$ bond distance increased in the calculated structure, $\mathbf{1}^{\prime}$. In general, the energy gap between the frontier molecular orbitals

Table 2. Selected structural parameters of $\mathbf{5}$ and $\mathbf{6}$ with related binuclear complexes.

\begin{tabular}{lcccc}
\hline Binuclear complexes & $\mathrm{d}_{\text {Nb-Nb }[\AA]}$ & $\mathrm{d}_{\mathrm{Nb}-\mathrm{E}[\AA]}^{\mathrm{a}}$ & $\mathrm{d}_{\mathrm{E}-\mathrm{E}[\AA],(\mathrm{E}=\mathrm{S}, \mathrm{Se})}$ & Ref. \\
\hline$\left[\mathrm{Nb}_{2}\left(\mu-\mathrm{S}_{2}\right)_{2}(\mathrm{NCS})_{8}\right]^{4-}$ & 2.913 & 2.51 & 2.012 & $19 \mathrm{a}$ \\
{$\left[\mathrm{Nb}_{2}\left(\mu-\mathrm{S}_{2}\right)_{2}\left(\mathrm{H}_{2} \mathrm{O}\right)_{8}\right]^{4+}$} & 2.898 & 2.497 & 2.004 & $19 \mathrm{a}$ \\
{$\left[\left(\mathrm{Cp}^{*} \mathrm{Nb}\right)_{2}\left(\mu-\mathrm{S}_{2}\right)_{2}\right], \mathbf{5}$} & 2.780 & 2.398 & 2.386 & $\mathrm{~b}$ \\
{$\left[\left(\mathrm{Cp}^{*} \mathrm{Nb}\right)_{2}\left(\mu-\mathrm{Se}_{2}\right)_{2}\right], \mathbf{6}$} & 2.805 & 2.476 & 2.363 & $\mathrm{~b}$ \\
{$\left[\mathrm{Nb}_{2} \mathrm{~S}_{4}\left(\mathrm{Et}_{2} \mathrm{NCS}_{2}\right)_{4}\right]$} & 2.892 & 2.564 & 2.033 & 53 \\
{$\left[\mathrm{Nb}_{2} \mathrm{Se}_{4}\left(\mathrm{Et}_{2} \mathrm{NCS}_{2}\right)_{4}\right]$} & 2.974 & 2.639 & 2.303 & 54 \\
{$\left[\mathrm{Nb}_{2} \mathrm{Se}_{4}\right]\left[\mathrm{Te}_{2} \mathrm{I}_{6}\right]_{2}$} & 2.926 & 2.613 & 2.310 & 54 \\
\hline
\end{tabular}

average Nb-E distances; ${ }^{\mathrm{b}}$ this work. 
(FMO) signifies the hardness/stability of the complexes. Here, the FMO analysis shows slightly higher HOMO (higher highest occupied molecular orbitals)LUMO (lowest unoccupied molecular orbitals) energy gap for $\mathbf{2}^{\prime}(2.30 \mathrm{eV})$ than $\mathbf{3}^{\prime}(2.26 \mathrm{eV})$, where $\mathbf{1}^{\prime}$ shows the least energy gap $(2.04 \mathrm{eV})$, indicates their relative hardness or thermodynamic stability. Among the chalcogen analogues the hardness decreases in the order of $\mathrm{S}>\mathrm{Se}>\mathrm{Te}$ (Table S2, Supplementary Information). Furthermore, molecular orbitals show the accumulation of electron density of HOMO on metals and $\mathrm{Se} 3$ atoms in $\mathbf{1}$ and only on metals in $\mathbf{2}$ and $\mathbf{3}$ wherein in the case of LUMO it is localized on both metals and Se1 in 1-3 (Figure S20, Supplementary Information).

The observed M-M bond distances of 2.51, 2.67 and $2.70 \AA$, in $\mathbf{1}^{\prime}, \mathbf{2}^{\prime}$ and $\mathbf{3}^{\prime}$, respectively signify a double bond. In addition, high WBI value of $0.77,0.91$ and 0.94 further elucidates the presence of a strong M-M bonding in $\mathbf{1}^{\prime}-\mathbf{3}^{\prime}$, respectively. Further, the NBO analysis displays the existence of two M-M bond formed by $\mathrm{d}_{\mathrm{z}}^{2} \sigma$ bond and $\mathrm{d}_{(\mathrm{x}-\mathrm{y})}^{22} \pi$ bond with the occupancy of 1.47 and 1.09, 1.46 and 1.04 (Figure 4) and 1.51 and 0.82 , respectively in $\mathbf{1}^{\prime}-\mathbf{3}^{\prime}$ (Figures S21 and S22, Supplementary Information), consistent with the double bond. Surprisingly, the NBO and Wiberg bond index analysis show a weak bonding between $\mathrm{Se} 1$ and $\mathrm{Se} 2$ in 1 due to the elongation of bond, whereas two $\mu$ Se ligands in $\mathbf{2}$ and $\mathbf{3}$ show a bonding interaction even though they are far in distance, through a $\pi$-bond (Figure S23, Supplementary Information). Among the two different type of Se ligands, $\mu$-Se and $\mu$-SePh, the earlier one has stronger bonding towards the metals than later in (Table S4, Supplementary Information). In case of $\mathbf{1}$ there is an additional strong covalent bond that exists between $\mathrm{Se} 2$ and $\mathrm{Se} 3$.

The optimized geometries of $\mathbf{5}^{\prime}$ and $\mathbf{6}^{\prime}$ appeared to be very different from that observed in the crystal structure. The E-E interaction $(\mathrm{E}=\mathrm{S}, \mathrm{Se})$ in one of the $\mathrm{E}_{2}^{2-}$ unit became weaker to form two $(\mu$-E) units which result the entire bond parameters to be different from the crystallographic structures. These changes can be described as valence isomerization where $\mathrm{Nb}(\mathrm{III})$ is oxidised to $\mathrm{Nb}(\mathrm{IV})$ by oxidation of $\left(\mu-\mathrm{E}_{2}\right)^{2-}$ to two $(\mu-$ $\mathrm{E})^{2-}$ so that the final structure corresponded to $\left[\mathrm{Cp}^{*}{ }_{2-}\right.$ $\left.\mathrm{Nb}_{2}^{\mathrm{IV}}\left\{\left(\mu-\mathrm{E}_{2}\right)^{2-}\right\}\left\{(\mu-\mathrm{E})^{2-}\right\}_{2}\right]$ similar to the case of $\left[\mathrm{Cp}_{2}{ }_{2} \mathrm{Mo}_{2}\left(\mu-\mathrm{Se}_{3}^{4}\right)_{2}\right]$ which optimized to $\left[\mathrm{Cp}^{*}{ }_{2} \mathrm{Mo}_{2}\right.$ $\left.\mathrm{III}(\mu \text {-Se2- })_{3}\right] .{ }^{56}$ That means that the structure of $\mathbf{5}$ and $\mathbf{6}$ are metastable with respect to $\mathbf{5}^{\prime}$ and $\mathbf{6}^{\prime}$, but there must be a significant kinetic barrier for its conversion which can attribute to their isolation from a reaction under drastic reaction conditions. In literature, similar geometry as that of $\mathbf{5}^{\prime}$ and $\mathbf{6}^{\prime}$ is identified in the case of molybdenum chalcogen complex. ${ }^{14 \mathrm{~b}}$ In the optimized geometry of $\mathbf{5}^{\prime}$ and $\mathbf{6}^{\prime}$ the M-M bond gets even shorter that signifies a partial double bond nature ${ }^{57}$ which makes the complex a stable 18 electron species. The molecular orbital displaying $\mathrm{M}-\mathrm{M}$ bonding interactions also suggest the existence of double bond (Figure S25, Supplementary Information). In addition, the Wiberg bond indices $c a$. 1 shows a very strong interaction between the metals in $\mathbf{5}^{\prime}$ and $\mathbf{6}^{\prime}$ (Table S4, Supplementary Information).

The molecular orbital study of $\mathbf{5}^{\prime}$ and $\mathbf{6}^{\prime}$ shows that the HOMO-LUMO energy gap increases in the order of $\mathbf{6}^{\prime}<\mathbf{5}^{\prime}$. Inspection of the electron density of the FMOs of $\mathbf{5}^{\prime}$ and $\mathbf{6}^{\prime}$ reveals that the HOMOs are mainly localized on the chalcogen atom and LUMOs are on metal atoms (Figure S24, Supplementary Information). Even though the bond between one of the $\left(\mu-E_{2}\right)^{2-}$ is getting elongated, there is a special bonding interaction between them which is clearly visible in HOMO11 (Figure S25, Supplementary Information). Natural charge analysis further displays the accumulation of more positive charge on Se atom in $\mathbf{6}^{\prime}$ in comparison with the $\mathrm{S}$ atom in $\mathbf{5}^{\prime}$ that provides more donation of

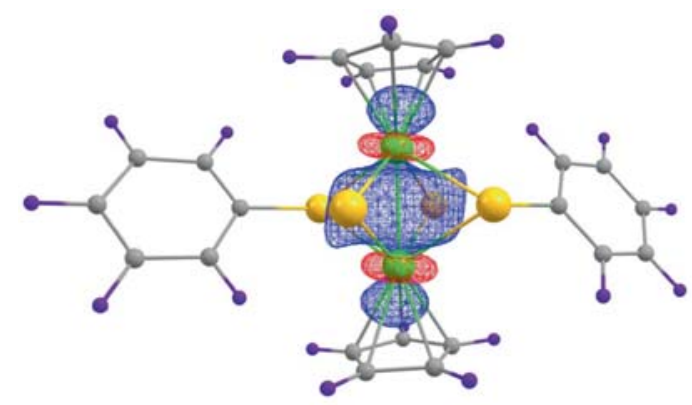

(a)

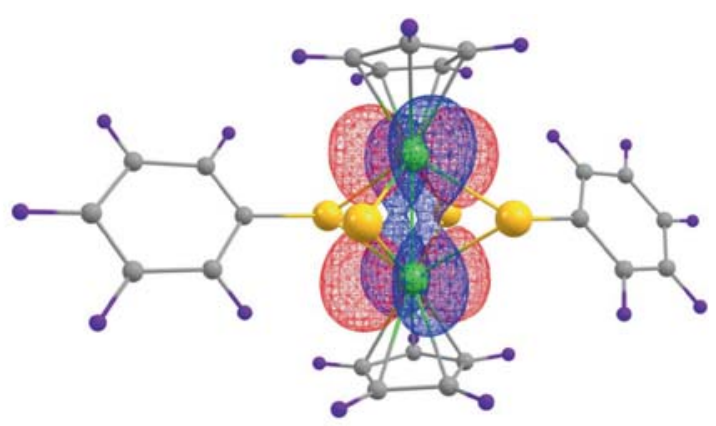

(b)

Figure 4. Molecular orbitals showing (a) Mo-Mo $\sigma$ bond and (b) $\pi$ bond in $\mathbf{2}^{\prime}$. 
electron towards the metal (Table S3, Supplementary Information).

\subsection{UV-Vis absorption spectroscopic study of complexes 2, 3, 5 and 6}

In order to elucidate the colour associated with these complexes, the UV-Vis absorption spectra of complexes 2, 3, 5 and $\mathbf{6}$ were recorded in dichloromethane (Figures S18 and S19, Supplementary Information). Unfortunately, we could not perform the UV-Vis absorption spectroscopy of $\mathbf{1}$ due to its highly sensitive behaviour in solution state, especially in chlorinated solvents. Complexes $\mathbf{2}$ and $\mathbf{3}$ show their absorption bands at 450, 586 and 769 and 415, 519 and $764 \mathrm{~nm}$ respectively. Complexes 5 and $\mathbf{6}$ show weak absorption band at about 314 and $358 \mathrm{~nm}$ respectively which corresponds to $\pi-\pi^{*}$ transition of the cyclopentadienyl ligands. In addition to that, low energy absorption bands at 483 and $500 \mathrm{~nm}$ have been identified which may be attributed to the significant intramolecular charge-transfer interactions.

To understand the nature of the electronic transitions, we performed time-dependent DFT calculations of excitation energies (see Tables S5-S9 and Figures S26S30, Supplementary Information). Even though we were unable to get the UV-Vis spectra of $\mathbf{1}$, the theoretical calculated result shows peaks shifted to higher wavelength region of the UV-Vis spectral region $(700-800 \mathrm{~nm})$. The peaks mainly arise due to the excitation from HOMO-2 and HOMO-3 to LUMO indicates the LMCT (ligand to metal charge transfer) and intramolecular charge transfer from $\mathrm{Se} 3$ to $\mathrm{Se} 1$. The profile of the TD-DFT simulated absorption spectra of $\mathbf{2}$ and 3 agree well with experiment and thus allow assignment of the absorption bands. The strongest peak in the visible region ( $\sim 586$ and $519 \mathrm{~nm})$ can be primarily assigned to the excitations from LMCT transition from nonbonding lone pairs on the bridging selenium atoms (HOMO-1) to predominantly metal-cantered MOs (LUMO), in contrast the less intense excitations at $760 \mathrm{~nm}$ which is due to MLCT (metal to ligand charge transfer) from MO of metal (HOMO) to non-bonding Se orbital in LUMO. The weak absorption in the $410-450 \mathrm{~nm}$ is primarily related to transitions from the Se ligand non-bonding MOs (HOMO-7, HOMO-5) to metal orbitals of LUMO. As there is a difference between the experimental and theoretical calculated geometry of $\mathbf{5}$ and 6, the exact comparison of electronic spectra was not possible. However, from the analysis it is well understood that the major contributing factor for the strong band around $400-500 \mathrm{~nm}$ is due to the LMCT.

\section{Conclusions}

This work describes a new synthetic strategy that enables us to isolate and characterize a series of chalcogen-bridged binuclear complexes of early transition metals. The crystal structures of the synthesized complexes represent three different types of chalcogen-bridged bimetallic complexes of groups 5 and 6 metals, such as $\left[\left(\mathrm{Cp}^{*} \mathrm{Nb}\right)_{2}\left(\mu-\mathrm{E}_{2}\right)_{2}\right](\mathrm{E}=\mathrm{S}$ and $\mathrm{Se})$, $\left[(\mathrm{Cp} * \mathrm{Cr})_{2}\left(\mu-\mathrm{Se}_{2} \mathrm{SePh}\right)_{2}\right]$ and $\left[(\mathrm{Cp} * \mathrm{M})_{2}(\mu-\mathrm{Se})_{2}(\mu-\right.$ $\mathrm{SePh})_{2}$ ] $(\mathrm{M}=\mathrm{Mo}$ and $\mathrm{W})$. In addition, combined theoretical and experimental studies ensure the presence of multiple bonds in these complexes.

\section{Supplementary Information (SI)}

Supplementary data contains the X-ray crystallographic files in CIF format for $\mathbf{1}, \mathbf{3}, \mathbf{5}$ and $\mathbf{6}$ CCDC 1915156 (1), 1868351 (3) 1868348 (5) and 1868349 (6) for this work. These data can be obtained free of charge from the Cambridge Crystallographic Data Centre via www.ccdc.cam.ac. uk/data_-request/cif. All additional information pertaining to characterization of the complexes 1-3, 5 and $\mathbf{6}$ using ESIMS technique and multinuclear NMR spectra, computational details are given in the Supplementary Information available at www.ias.ac.in/chemsci.

\section{Acknowledgements}

This work was supported by the Council of Scientific \& Industrial Research (CSIR) (Project No. 01(2939)/18/emrii), New Delhi, India. DST-FIST, India, is gratefully acknowledged for the HRMS facility. M. B., R. P., M. G. C. and B. R. are grateful to IIT Madras and C.N. is grateful to DST-INSPIRE, India for fellowship. The computational facility of IIT Madras is gratefully acknowledged. We thank Dr. C. Ghosh for X-ray data collection and Dr. B. Varghese and Mr. V. Ramkumar for X-ray structure analysis.

\section{References}

1. (a) Riaz U, Curnow O J and Curtis M D 1994 Desulfurization of Organic Sulfur Compounds Mediated by a Molybdenum /Cobalt/Sulfur Cluster J. Am. Chem. Soc. 116 4357; (b) Hales B J, Case E E, Morningstar J E, Dzeda M F and Mauterer L A 1986 Isolation of a New Vanadium-Containing Nitrogenase from Azotobacter vinelandii Biochemistry 257251

2. (a) Herbst K, Monari M and Brorson M 2002 Molecular Metal Sulfide Cluster Model for Substrate Binding to Oil-Refinery Hydrodesulfurization Catalysts Inorg. Chem. 41 1336; (b) Burgess B K and Lowe D 1996 Mechanism of Molybdenum Nitrogenase J. Chem. Rev. 96 2983; (c) Wakabayashi T, Ishii Y, Murata T, Mizobe Y and Hidai M 1995 Stereoselective Addition of 
Carboxylic Acids to Electron Deficient Acetylenes Catalyzed by the $\mathrm{PdMo}_{3} \mathrm{~S}_{4}$ Cubane-Type Cluster Tetrahedron Lett. 365585

3. (a) E W Abel, F G A Stone and G E Wilkinson (Eds.) 1995 Comprehensive Organometallic Chemistry II (New York: Pergamon); (b) D M P Mingos and R H Crabtree (Eds.) 2007 Comprehensive Organometallic Chemistry III (New York: Pergamon)

4. (a) Perla L G and Sevov S C $2015\left[\mathrm{Bi}_{12} \mathrm{Ni}_{7}(\mathrm{CO})_{4}\right]^{4-}$ : Aggregation of Intermetalloid Clusters by Their Thermal Deligation and Oxidation Inorg. Chem. 54 8401; (b) Perla L G and Sevov S C 2016 Cluster Fusion: Face-Fused Nine-Atom Deltahedral Clusters in $\left[\mathrm{Sn}_{14}\right.$ $\mathrm{Ni}(\mathrm{CO})]^{4-}$ Angew. Chem. Int. Ed. 55 6721; (c) Goicoechea J M and Sevov S C 2006 Deltahedral Germanium Clusters: Insertion of Transition-Metal Atoms and Addition of Organometallic Fragments $J$. Am. Chem. Soc. 128 4155; (d) Sahoo S, Dhayal R S, Varghese B and Ghosh S 2009 Unusual Open EightVertex Oxamolybdaboranes: Structural Characterizations of $\left(\eta^{5}-\mathrm{C}_{5} \mathrm{Me}_{5} \mathrm{Mo}\right)_{2} \mathrm{~B}_{5}(\mu-\mathrm{OEt}) \mathrm{H}_{6} \mathrm{R} \quad(\mathrm{R}=\mathrm{H}$ and n-BuO) Organometallics 281586

5. (a) Stevenson D L and Dahl L F 1967 Organometallic Sulfur Complexes. VIII. The Molecular Structure of a Doubly Sulfur-Bridged Dimeric Complex of Molybdenum(V), $\left[\mathrm{C}_{5} \mathrm{H}_{5} \mathrm{MoO}\right]_{2} \mathrm{~S}_{2}$, Containing a Molybdenum-Molybdenum Interaction J. Am. Chem. Soc. 89 3721; (b) Tatsumi K, Inoue Y, Kawaguchi H, Kohsaka M, Nakamura A, Cramer R E, VanDoorne W, Taogoshi G J and Richmann P N 1993 Structural Diversity of Sulfide Complexes Containing Half-Sandwich Cp*Ta and $\mathrm{Cp} * \mathrm{Nb}$ Fragments Organometallics 12352

6. (a) Weberg R, Haltiwanger R C and Rakowski D M 1985 Structure and Reactivity of $\left[\mathrm{CpFeS}_{2}\right]_{2}$ Organometallics 4 1315; (b) Adams R D, Horvath I T and Mathur P 1984 Cluster Synthesis. 6. The Unusual Structures, Bonding, and Reactivity of Some SulfidoBridged Tungsten-Osmium Carbonyl Cluster Compounds J. Am. Chem. Soc. 1066296

7. Simonnet-Jégat C and Sécheresse F 2001 Binary Vanadium Chalcogenide Complexes Chem. Rev. 1012601

8. (a) Bolinger C M and Rauchfuss T B 1982 Structure of $\left(\mathrm{C}_{5} \mathrm{H}_{4} \mathrm{CH}_{3}\right)_{2} \mathrm{~V}_{2} \mathrm{~S}_{5}$ and Its Acetylene Addition Reaction Organometallics 1 1551; (b) Bolinger C M, Rauchfuss T B and Rheingold A L 1983 Synthesis and Structures of $\left(i-\mathrm{PrC}_{5} \mathrm{H}_{4}\right)_{2} \mathrm{~V}_{2} \mathrm{~S}_{4}$ and $\left(\mathrm{C}_{5} \mathrm{H}_{5}\right)_{2} \mathrm{~V}_{2} \mathrm{~S}_{2}\left(\mathrm{~S}_{2} \mathrm{C}_{2}\left(\mathrm{CF}_{3}\right)_{2}\right)$ : The Influence of $\pi$-Bonding on the Geometry of the $\mu$-S Ligand J. Am. Chem. Soc. 1056321

9. (a) Adams R D and Wang S 1985 Two-Site Reactivity in a Ligand-Bridged Cluster. The Reaction of $\mathrm{Os}_{4}(-$ $\mathrm{CO})_{12}\left(\mu_{3}-\mathrm{S}\right)$ with Terminal Acetylenes Organometallics 4 1902; (b) Linck R C, Pafford R J and Rauchfuss T B 2001 Heterolytic and Homolytic Activation of Dihydrogen at an Unusual Iridium (II) Sulfide J. Am. Chem. Soc. 1238856

10. Ohki Y, Matsuura N, Marumoto T, Kawaguchi $\mathrm{H}$ and Tatsumi K 2003 Heterolytic Cleavage of Dihydrogen Promoted by Sulfido-Bridged Tungsten-Ruthenium Dinuclear Complexes J. Am. Chem. Soc. 1257978

11. Adams R D and Kwon O-S 2003 Syntheses and Reactivity of the Diselenido Molybdenum-Manganese Complex CpMoMn $(\mathrm{CO})_{5}\left(\mu-\mathrm{Se}_{2}\right)$ Inorg. Chem. 426175
12. Adams R D, Captain B, Kwon O-S and Miao S 2003 New Disulfido Molybdenum-Manganese Complexes Exhibit Facile Addition of Small Molecules to the Sulfur Atoms Inorg. Chem. 423356

13. Dubois R M, Jagirdar B, Noll B and Dietz S 1996 In: Syntheses, Structures, and Reactions of Cyclopentadienyl Metal Complexes with Bridging Sulfur Ligands E I Stiefel and K Mazumoto (Eds.) ACS Symposium. Series: 653; Washington DC p. 269

14. (a) Appel A M, DuBois D L and DuBois M R 2005 Molybdenum-Sulfur Dimers as Electrocatalysts for the Production of Hydrogen at Low Overpotentials J. Am. Chem. Soc. 127 12717; (b) Appel A M, Lee S -J, Franz J A, DuBois D L and DuBois M R 2009 Free Energy Landscapes for $\mathrm{S}-\mathrm{H}$ Bonds in $\mathrm{Cp}^{*}{ }_{2} \mathrm{Mo}_{2} \mathrm{~S}_{4}$ Complexes J. Am. Chem. Soc. 1315224

15. DuBois M R, VanDerveer M C, DuBois D L, Haltiwanger R C and Miller W K 1980 Characterization of Reactions of Hydrogen with Coordinated Sulfido Ligands J. Am. Chem. Soc. 1027456

16. Denisov N T, Shuvalova N I, Shilov A E, Pasynskij A A, Kolobkov B I and Eremenko I L 1993 Reduction of molecular nitrogen in a protic medium with participation of Fe-S and Mo-Fe-S clusters Kinet. Katal. 34858

17. Rakitin Yu V and Kalinnikov V T 1994 Sovremennaya magnetokhimiya [Modern magnetochemistry] (Nauka: St-Peterburg) p. 276 p (in Russian)

18. (a) Keim W and Zhu Y 1990 Catalytic Desulfurization Reactions Using Triple Bond Dimolybdenum and Ditungsten Organometallic Complexes J. Mol. Catal. 58 355; (b) Brunner H, Wachter J and Wintergerst H 1982 Reaktivität der $\mathrm{m}-\mathrm{m}$-mehrfachbindung in metallcarbonyl-derivaten: V. Die reaktion von $\left(\eta_{5}-\mathrm{C}_{5} \mathrm{Me}_{5}\right)_{2-}$ $\mathrm{M}_{2}(\mathrm{CO})_{4}(\mathrm{M}=\mathrm{Mo}, \mathrm{W})$ MIT elementarem selen $J$. Organomet. Chem. 235 77; (c) Hong M, Cao R, Kawaguchi $\mathrm{H}$ and Tatsumi K 2002 Synthesis and Reactions of Group 6 Metal Half-Sandwich Complexes of 2,2-Dicyanoethylene-1,1-dichalcogenolates $\quad\left[\left(\mathrm{Cp}^{*}\right) \mathrm{M}\left\{\mathrm{E}_{2}\right.\right.$ $\left.\left.\mathrm{CdC}(\mathrm{CN})_{2}\right\}_{2}\right]^{-}(\mathrm{M}=\mathrm{Mo}, \mathrm{W} ; \mathrm{E}=\mathrm{S}$, Se $)$ Inorg. Chem. 41 4824; (d) Volkov S V, Kolesnichenko V L and Timoshchenko N. I 1988 A New Family of Binuclear Molybdenum(V) and Tungsten(V) Chalcohalides J. Coord. Chem. 17 367; (e) Krishnamoorthy B S, Thakur A, Chakrahari K K V, Bose S K, Hamon P, Roisnel T, Kahlal S, Ghosh S and Halet J-F 2012 Theoretical and Experimental Investigations on Hypoelectronic Heterodimetallaboranes of Group 6 Transition Metals Inorg. Chem. 51 10375; (f) Shi Y -C 2004 Reactions of Mo-Mo singly-bonded complexes $\left[\left(\eta^{5}-\mathrm{RC}_{5} \mathrm{H}_{4}\right)_{2} \mathrm{Mo}_{2}(\mathrm{CO})_{6}\right]$ with diphenylditelluride in the presence of ${ }^{n} \mathrm{Bu}_{4} \mathrm{NI}$ Crystal structures of complexes $\left[\left(\eta^{5}-\mathrm{C}_{5} \mathrm{H}_{5}\right) \mathrm{Mo}(\mathrm{CO})_{3} \mathrm{Te}\right]$ and cis/ae- $\left[\left(\eta^{5}-\mathrm{C}_{2} \mathrm{H}_{5} \mathrm{O}_{2} \mathrm{CC}_{5}\right.\right.$ $\left.\left.\mathrm{H}_{4}\right)_{2} \mathrm{Mo}_{2}(1-\mathrm{Te})_{2}(1-\mathrm{TePh})_{2}\right]$ Polyhedron 23 1663; (g) Song L -C, Shi Y -C and Zhu W -F 1999 Synthesis and characterization of doubly bonded and quadruply bridged trans/anti and trans/syn- $\left(\eta^{5}-\mathrm{RC}_{5} \mathrm{H}_{4}\right)_{2} \mathrm{M}_{2}(\mu-\mathrm{Se})_{2}(\mu-$ $\mathrm{SePh})_{2}(\mathrm{M}=\mathrm{Mo}, \mathrm{W})$ isomers Polyhedron 18 2163; (h) Shi Y -C and Song L -C 2004 Syntheses and crystal structures of quadruply bridged $\mathrm{Mo}_{2} \mathrm{Se}_{4}$ complexes containing functionalized cyclopentadienyl ligands: trans/ anti- $\left(\eta^{5}-\mathrm{CH}_{3} \mathrm{O}_{2} \mathrm{CC}_{5} \mathrm{H}_{4}\right)_{2} \mathrm{Mo}_{2}(\mu-\mathrm{Se})_{2}\left(\mu-\mathrm{SeCH}_{2} \mathrm{Ph}\right)(\mu-\mathrm{SePh})$ and trans/syn- $\left(\eta^{5}-\mathrm{C}_{2} \mathrm{H}_{5} \mathrm{O}_{2} \mathrm{CC}_{5} \mathrm{H}_{4}\right)_{2} \mathrm{Mo}_{2}(\mu-\mathrm{Se})_{2}(\mu-\mathrm{SePh})_{2} J$. Coord. Chem. 57731 
19. (a) Sokolov M N, Molina R H, Elsegood M R J, Heath S L, Clegg W and Sykes A G 1997 Preparation, structure and reactivity of the di- $\mu$-disulfido $\mathrm{Nb}_{2}^{\text {IV }}$ aqua ion $\left[\mathrm{Nb}_{2}\left(\mu-\mathrm{S}_{2}\right)_{2}\left(\mathrm{H}_{2} \mathrm{O}\right)_{8}\right]^{4+}$, the structure of $\left[\mathrm{Nb}_{2}(\mu-\right.$ $\left.\left.\mathrm{S}_{2}\right)_{2}(\mathrm{NCS})_{8}\right]^{4-}$, and properties of the related $(\mu-\mathrm{S})_{2}$ aqua ion J. Chem. Soc., Dalton Trans. 2059; (b) Bolinger C M, Rauchfuss T B and Wilson S R 1982 Synthesis of Organovanadium Sulfide Cluster Compounds via Bis(methyicyclopentadienyl)divanadium Tetrasulfide J. Am. Chem. Soc. 1047313

20. (a) Bolinger C M, Rauchfuss T B and Wilson S R 1984 4-Phenyl-1,2,4-triazoline-3,5-dione: A Prosthesis for the $\mu-\eta^{1}-S_{2}$ Ligand in Organovanadium Sulfide Chemistry J. Am. Chem. Soc. 106 7800; (b) Bose S K, Geetharani K, Ramkumar V, Varghese B and Ghosh S 2010 Chemistry of Vanadaboranes: Synthesis, Structures, and Characterization of Organovanadium Sulfide Clusters with Disulfido Linkage Inorg. Chem. 49 2881; (c) Bose S K, Geetharani K, Sahoo S, Reddy K H K; Varghese B, Jemmis E D and Ghosh S 2011 Synthesis, Characterization, and Electronic Structure of New Type of Heterometallic Boride Clusters. Inorg. Chem. 50 9414; (d) Sahoo S, Mobin S. M and Ghosh S 2010 Direct Insertion of Sulphur, Selenium and Tellurium atoms into Metallaborane Cages using Chalcogen Powders J. Organomet. Chem. 695 945; (e) Bose S K, Mobin S M and Ghosh S 2011 Metallaheteroborane Clusters of Group 5 Transition Metals Derived from Dichalcogenide Ligands J. Organomet. Chem. 696 3121

21. Nowak I and Ziolek M 1999 Niobium Compounds: Preparation, Characterization, and Application in Heterogeneous Catalysis Chem. Rev. 993603

22. Rogachev A V, Gushchin A L, Abramov P A, Kozlova E A, Vicent C, Piryazev D, Barlow A, Samoc M, Humphrey M G, Llusar R, Fedin V P and Sokolov M N 2015 Binuclear Sulfide Niobium Clusters Coordinated by Diimine Ligands: Synthesis, Structure, Photocatalytic Activity and Optical Limiting Properties Eur. J. Inorg. Chem. 2865

23. (a) Barik S K, Rao C E, Yuvaraj K, Jagan R, Kahlal S, Halet J-F and Ghosh S 2015 Electron-Precise 1,3Bishomocubanes - A Combined Experimental and Theoretical Study Eur. J. Inorg. Chem. 5556; (b) Chakrahari K K V, Thakur A, Mondal B, Ramkumar V and Ghosh S 2013 Hypoelectronic Dimetallaheteroboranes of Group 6 Transition Metals Containing Heavier Chalcogen Elements Inorg. Chem. 52 7923; (c) Joseph B, Barik S K, Ramalakshmi R, Kundu G, Roisnel T, Dorcet V and Ghosh S 2018 Chemistry of Triple-Decker Sandwich Complexes Containing FourMembered Open $\mathrm{B}_{2} \mathrm{E}_{2}$ Rings $(\mathrm{E}=\mathrm{S}$ or $\mathrm{Se})$ Eur. J. Inorg. Chem. 2045

24. (a) Roy D K, Bose S K, Geetharani K, Chakrahari K K V, Mobin S M and Ghosh S 2012 Synthesis and Structural Characterization of New Divanada- and Diniobaboranes Containing Chalcogen Atoms Chem. Eur. J. 18 9983; (b) Geetharani K, Bose S K, Basak D, Suresh V M and Ghosh S 2011 A new entry into ferraborane chemistry: Synthesis and characterization of heteroferraborane complexes Inorg. Chim. Acta 372 42; (c) Shankhari P, Roy D K, Geetharani K, Anju R S,
Varghese B and Ghosh S 2013 Synthesis and structural characterization of group 5 dimetallaheteroboranes $J$. Organomet. Chem. 747 249; (d) Chakrahari K K V, Sharmila D, Barik S K, Mondal B, Varghese B. and Ghosh S 2014 Hypoelectronic Metallaboranes: Synthesis, Structural Characterization and Electronic Structures of Metal-Rich Cobaltaboranes J. Organomet. Chem. 749188

25. (a) Kar S, Saha K, Saha S, Bakthavachalam K, Dorcet V and S. Ghosh 2018 Trimetallic Cubane-Type Clusters: Transition-Metal Variation as a Probe of the Roots of Hypoelectronic Metallaheteroboranes Inorg. Chem. 57 10896; (b) Joseph B, Saha K, Prakash R, Nandi C, Roisnel T and Ghosh S 2018 Chalcogenolato-bridged dinuclear half sandwich complexes of ruthenium and iridium Inorg. Chim. Acta 483 106; (c) Ramalakshmi R, Saha K, Paul A and Ghosh S 2016 Reactivity of $\left[\mathrm{Cp} * \mathrm{Mo}(\mathrm{CO})_{3} \mathrm{Me}\right]$ with chalcogenated borohydrides $\mathrm{Li}\left[\mathrm{BH}_{2} \mathrm{E}_{3}\right]$ and $\mathrm{Li}\left[\mathrm{BH}_{3} \mathrm{EFc}\right] \quad\left(\mathrm{Cp}^{*}=\left(\eta^{5}-\mathrm{C}_{5} \mathrm{Me}_{5}\right)\right.$; $\mathrm{E}=\mathrm{S}$, Se or Te; $\mathrm{Fc}=\left(\mathrm{C}_{5} \mathrm{H}_{5}-\mathrm{Fe}-\mathrm{C}_{5} \mathrm{H}_{4}\right)$ J. Chem. Sci. 128 1025; (d) Chakrahari K K V, Dhayal R S and Ghosh S 2011 Synthesis and characterization of binuclear $\mu$-oxo and $\mu$-telluro molybdenum(V) complexes, $[\mathrm{Cp} * \mathrm{Mo}(\mathrm{O})(\mu-\mathrm{Te})]_{2}$ Polyhedron 30 1048; (e) Anju R S, Saha K, Mondal B, Dorcet V, Roisnel T, Halet J -F and Ghosh S 2014 Chemistry of Diruthenium Analogue of Pentaborane(9) With Heterocumulenes: Toward Novel Trimetallic Cubane-Type Clusters Inorg. Chem. 53 10527

26. (a) Barik S K, Chowdhury M G, De S, Parameswaran P and Ghosh S 2016 Extended Sandwich Molecules Displaying Direct Metal-Metal Bonds Eur. J. Inorg. Chem. 4546; (b) Ramalakshmi R, Saha K, Roy D K, Varghese B, Phukan A K and Ghosh S 2015 New Routes to a Series of $\sigma$-Borane/Borate Complexes of Molybdenum and Ruthenium Chem. Eur. J. 21 17191; (c) Joseph B, Gomosta S, Barik S, Sinha S K, Roisnel T, Dorcet V, Halet J-F and Ghosh S 2018 Synthesis and characterization of diruthenaborane analogues of pentaborane(11) and hexaborane(10) J. Organomet. Chem. 86529

27. Chowdhury M G, Barik S K, Saha K, Kirubakaran B, Banerjee A, Ramkumar V and Ghosh S 2018 Electron Precise Group 5 Dimetallaheteroboranes $[\{\mathrm{CpV}$ $\left.(\mu-\mathrm{EPh})\}_{2}\left\{\mu-\eta^{2}: \eta^{2}-\mathrm{BH}_{3} \mathrm{E}\right\}\right]$ and $\left[\{\mathrm{CpNb}(\mu-\mathrm{EPh})\}_{2}\{\mu-\right.$ $\left.\left.\eta^{2}: \eta^{2}-\mathrm{B}_{2} \mathrm{H}_{4} \mathrm{E}\right\}\right] \quad(\mathrm{E}=\mathrm{S}$ or $\mathrm{Se})$ Inorg. Chem. 57985

28. Heintz R A, Haggerty B S, Wan H, Rheingold A L and Theopold K H 1992 [ $\left\{\mathrm{Cp} * \mathrm{Cr}\left(\mu_{3}-\mathrm{H}\right)\right)$,]-a Paramagnetic Chromium Hydride with a Cubane Structure Angew. Chem. Int. Ed. 311077

29. (a) Green M L H, Hubert J D and Mountford P 1990 Synthesis of the $\mathrm{W} \equiv \mathrm{W}$ triply bonded dimers $\left[\mathrm{W}_{2}(\eta-\right.$ $\left.\mathrm{C}_{5} \mathrm{H}_{4} \mathrm{R}\right)_{2} \mathrm{X}_{4}$ ] $\left(\mathrm{X}=\mathrm{Cl}, \mathrm{R}=\mathrm{Me}\right.$ or $\left.{ }^{\mathrm{i}} \mathrm{Pr} ; \mathrm{X}=\mathrm{Br}, \mathrm{R}={ }^{\mathrm{i}} \mathrm{Pr}\right)$ and $\mathrm{X}$-ray crystal structures of $\left[\mathrm{W}\left(\eta-\mathrm{C}_{5} \mathrm{H}_{4}^{\mathrm{i}} \mathrm{Pr}\right) \mathrm{Cl}_{4}\right]$ and $\left[\mathrm{W}_{2}\left(\eta-\mathrm{C}_{5} \mathrm{H}_{4}^{\mathrm{i}} \mathrm{Pr}\right)_{2} \mathrm{Cl}_{4}\right]$ J. Chem. Soc., Dalton Trans. 3793; (b) Dhayal R S, Sahoo S, Ramkumar V and Ghosh S 2009 Substitution at boron in molybdaborane frameworks: Synthesis and characterization of isomeric $\left(\eta^{5}-\mathrm{C}_{5} \mathrm{Me}_{5} \mathrm{Mo}\right)_{2} \mathrm{~B}_{5} \mathrm{H}_{\mathrm{n}} \mathrm{X}_{\mathrm{m}}$ (when $\mathrm{X}=\mathrm{Cl}: \mathrm{n}=5,7,8$; $\mathrm{m}=4,2,1$ and $\mathrm{X}=\mathrm{Me}: \mathrm{n}=6,7 ; \mathrm{m}=3,2) J$. Organomet. Chem. 694237 
30. Okamoto T, Yasuda H, Nakamura A, Kai Y, Kanehisa $\mathrm{N}$ and Kasai N 1988 Synthesis and Catalysis of Novel Mono-and Bis(diene) Complexes of Niobium and X-ray Structures of Binuclear $\left[\mathrm{Nb}(\mu-\mathrm{Cl})\left(\mathrm{C}_{5} \mathrm{H}_{5}\right)(\right.$ s-cisbutadiene $)]_{2}$ and Mononuclear $\mathrm{Nb}\left(\mathrm{C}_{5} \mathrm{H}_{5}\right)($ s-cis-2,3dimethylbutadiene) $)_{2}$ J. Am. Chem. Soc. 1105008

31. Ryschkewitsch G E and Nainan K C 1974 Octahydrotriborate (1-) $\left[\mathrm{B}_{3} \mathrm{H}_{8}\right]$ Salts Inorg. Synth. 15113

32. (a) Aldridge S, Fehlner T P and Shang M 1997 Directed Synthesis of Chromium and Molybdenum Metallaborane Clusters. Preparation and Characterization of $\left(\mathrm{Cp}^{*} \mathrm{Cr}\right)_{2} \mathrm{~B}_{5} \mathrm{H}_{9}, \quad\left(\mathrm{Cp}^{*} \mathrm{Mo}\right)_{2} \mathrm{~B}_{5} \mathrm{H}_{9}, \quad$ and $(\mathrm{Cp} * \mathrm{MoCl})_{2} \mathrm{~B}_{4} \mathrm{H}_{10}$ J. Am. Chem. Soc. 119 2339; (b) Dhayal R S, Sahoo S, Reddy K H K, Mobin S M, Jemmis E D and Ghosh S 2010 Vertex-Fused Metallaborane Clusters: Synthesis, Characterization and Electronic Structure of $\left[\left(\eta^{5}-\mathrm{C}_{5} \mathrm{Me}_{5} \mathrm{Mo}\right)_{3} \mathrm{MoB}_{9} \mathrm{H}_{18}\right]$ Inorg. Chem. 49 900; (c) Weller A S, Shang M and Fehlner T P 1999 Synthesis of Mono- and Ditungstaboranes from Reaction of $\mathrm{Cp}^{*} \mathrm{WCl}_{4}$ and $\left[\mathrm{Cp}^{*} \mathrm{WCl}_{2}\right]_{2}$ with $\mathrm{BH}_{3}$ thf or $\mathrm{LiBH}_{4} \quad\left(\mathrm{Cp}^{*}=\eta^{5}\right.$ $\mathrm{C}_{5} \mathrm{Me}_{5}$ ). Control of Reaction Pathway by Choice of Monoboron Reagent and Oxidation State of Metal Center Organometallics 18 53; (d) Geetharani K, Bose S K, Pramanik G, Saha T K, Ramkumar V and Ghosh S 2009 An Efficient Route to Group 6 and 8 Metallaborane Compounds: Synthesis of arachno$\left[\mathrm{Cp} * \mathrm{Fe}(\mathrm{CO}) \mathrm{B}_{3} \mathrm{H}_{8}\right]$ and closo- $\left[(\mathrm{Cp} * \mathrm{M})_{2} \mathrm{~B}_{5} \mathrm{H}_{9}\right] \quad(\mathrm{M}=$ Mo, W) Eur. J. Inorg. Chem. 1483

33. Prakash R, Bakthavachalam K, Varghese B and Ghosh S 2017 Chlorination of the terminal hydrogen atoms in the hydrogen-rich group 5 dimetallaboranes $(\mathrm{Cp} * \mathrm{M})_{2}\left(\mathrm{~B}_{2} \mathrm{H}_{6}\right)_{2}(\mathrm{M}=\mathrm{Nb}$, Ta) J. Organomet. Chem. 846372

34. Sheldrick G M 2015 Crystal structure refinement with SHELXL Acta Cryst. C $\mathbf{7 1} 3$

35. Frisch M J, Trucks G W, Schlegel H B, Scuseria G E, RobbMA, Cheeseman J R, Scalmani G, BaroneV, Mennucci B, Petersson G A, Nakatsuji H, Caricato M, Li X, Hratchian H P, Izmaylov A F, Bloino J, Zheng G, Sonnenberg J L, Hada M, Ehara M, Toyota K, Fukuda R, Hasegawa J, Ishida M, Nakajima T, Honda Y, Kitao O, Nakai H, Vreven T, Montgomery J A. Jr, Peralta J E, Ogliaro F, Bearpark M, Heyd J J, Brothers E, Kudin K N, Staroverov V N, Keith T, Kobayashi R, Normand J, Raghavachari K, Rendell A, Burant J C, Iyengar S S, Tomasi J, Cossi M, Rega N, Millam J M, Klene M, Knox J E, Cross J B, Bakken V, Adamo C, Jaramillo J, Gomperts R, Stratmann R E, Yazyev O, Austin A J, Cammi R, Pomelli C, Ochterski JW, Martin R L, Morokuma K, Zakrzewski V G, Voth G A, Salvador P, Dannenberg J J, Dapprich S, Daniels A D, Farkas O, Foresman J B, Ortiz J V, Cioslowski J and Fox D J 2010 Gaussian 09, Revision C.01; Gaussian, Inc.: Wallingford, CT

36. Schmider H and Becke A D 1998 Optimized density functionals from the extended G2 test set. J. Chem. Phys. 1089624

37. Dolg M, Stoll H and Preuss H A 1993 A combination of quasirelativistic pseudopotential and ligand field calculations for lanthanoid compounds Theor. Chim. Acta $\mathbf{8 5} 441$
38. Wiberg K B 1968 Application of the pople-santry-segal CNDO method to the cyclopropylcarbinyl and cyclobutyl cation and to bicyclobutane Tetrahedron 241083

39. (a) Reed A E, Weinhold F and Curtiss L A 1988 Intermolecular interactions from a natural bond orbital, donor-acceptor viewpoint Chem. Rev. 88 899; (b) Weinhold F and Landis R 2005 Valency and bonding: A natural bond orbital donor-acceptor perspective (Cambridge: U.K.: Cambridge University Press); (c) King R B 1999 Topological Aspects of the Skeletal Bonding in "Isocloso" Metallaboranes Containing "Anomalous" Numbers of Skeletal Electrons Inorg. Chem. 38 5151; (d) King R B 2000 Face-localized bonding models for borane cage ligands intransition metal coordination chemistry Inorg. Chim. Acta 300537

40. Chemcraft - graphical software for visualization of quantum chemistry computations. https://www.chem craftprog.com.

41. (a) Hashimoto H, Shang M and Fehlner T P 1996 Reactions of an Electronically Unsaturated Chromaborane. Coordination of $\mathrm{CS}_{2}$ to $\left(\eta^{5}-\mathrm{C}_{5} \mathrm{Me}_{5}\right)_{2} \mathrm{Cr}_{2} \mathrm{~B}_{4} \mathrm{H}_{8}$ and Its Hydroboration to a Methanedithiolato Ligand Organometallics 15 1963; (b) Ho J, Deck K J, Nishihara Y, Shang M and Fehlner T P 1995 High Yield Synthesis and Characterization of Chromaboranes. Comparison of the Geometric, Electronic, and Chemical Properties of an Electronically Unsaturated $\left(\eta^{5}-\right.$ $\left.\mathrm{C}_{5} \mathrm{H}_{5}\right)_{2} \mathrm{Cr}_{2} \mathrm{~B}_{4} \mathrm{H}_{8}$ ) Cluster with Its Saturated Derivative $\left(\eta^{5}-\mathrm{C}_{5} \mathrm{H}_{5}\right)_{2} \mathrm{Cr}_{2}(\mathrm{CO})_{2} \mathrm{~B}_{4} \mathrm{H}_{6}$ J. Am. Chem. Soc. 11710292

42. Kornienko A Y, Emge T J and Brennan J G 2001 Chalcogen-Rich Lanthanide Clusters: Cluster Reactivity and the Influence of Ancillary Ligands on Structure J. Am. Chem. Soc. 12311933

43. (a) Pasynskii A A, Denisov F S, Torubaev Yu V, Semenova N I, Novotortsev V M, Ellert O G, Nefedov S E and Lyssenko K A 2000 Antiferromagnetic complexes with metal-metal bonds Part XXIX. Synthesis and molecular structures of heterochalcogenide binuclear complex $\left[\pi-\left(\mathrm{CH}_{3} \mathrm{C}_{5} \mathrm{H}_{4}\right) \mathrm{Cr}(\mu-\mathrm{SPh})\right]_{2} \mathrm{Se}$ and trinuclear mixed-metal cluster $\left[\pi-\left(\mathrm{CH}_{3} \mathrm{C}_{5} \mathrm{H}_{4}\right)_{2} \mathrm{Cr}_{2}(\mu-\right.$ $\mathrm{SPh})]\left(\mu_{3}-\mathrm{S}\right)\left(\mu_{3}-\mathrm{Se}\right) \mathrm{Co}(\mathrm{CO})_{2} J$. Organomet. Chem. 612 9; (b) Pasynskii A A, Eremenko I L, Rakitin Y-V, Novotortsev V M, Kalinnikov V T, Aleksandrov G G and Struchkov Y-T 1979 Antiferromagnetic Complexes Involving Metal-Metal Bonds I Synthesis and Molecular Structure of An Antiferromagnetic Dimer with a $\mathrm{Cr}-\mathrm{Cr}$ bond J. Organomet. Chem. 16557

44. McPhail A T and Sim G A 1968 Metal-Carbonyl and Metal-Nitrosyl Complexes. Part VI. The Crystal and Molecular Structure of trans-Di- $\mu$-phenylthio-dinitrosylbis-( $\pi$-cyclopentadienyl)dichromium(I) J. Chem. Soc. A 1858

45. (a) Eremenko I L, Pasynskii A, Kalinnikov V T, Struchkov Y-T and Aleksandrov G G 1981 Nitrosylation of Dicyclopentadienyldi( $\mu$-tert-butylthiolato $)(\mu$ sulfido)-dichromium giving Tert-butylsulfanic Group. Molecular Structures of the Binuclear Complex $\mathrm{Cp}(\mathrm{NO}) \mathrm{Cr}\left(\mu-\mathrm{SCMe}_{3}\right)\left(\mu-\mathrm{S}-\mathrm{SCMe}_{3}\right) \mathrm{Cr}(\mathrm{NO}) \mathrm{Cp}$ and Monomer $\mathrm{CpCr}(\mathrm{NO})_{2}(\mathrm{ONO})$ Inorg. Chim. Acta 52 107; (b) Goh L Y, Tay M S, Mak T C W and Wang R G 1992 Thiolate-Bridged Dichromium Complexes. 
Syntheses and Crystal Structures of $\left[\mathrm{CpCr}(\mathrm{CO})_{2}(-\right.$ $\mathrm{SPh})]_{2}$ and $[\mathrm{CpCr}(\mathrm{SPh})]_{2} \mathrm{~S}$ Organometallics 111711

46. Rakoczy H, Schollenberger M, Nuber B and Ziegler M L $1994[\mathrm{CpMo}(\mu-\mathrm{Se})(\mu-\mathrm{SePh})]_{2}$ : Ein vierfach chalkogenato-verbrückter Dimolybdän-Komplex mit ungewöhnlicher Struktur J. Organomet. Chem. 467217

47. Pasynskii A A, Blokhin A I, Torubaev Y-V and Dobrokhotova Z-V 2011 Synthesis and Molecular Structures of Tris(thio- and Selenophenyl)stannyl Complexes of Cyclopentadienylcarbonylnitrosylmanganese and Their Reaction Products with Tungsten Carbonyl Russ. J. Coord. Chem. 37879

48. Kolesnichenko V L, Rybakov V B, Aslanov L A and Volkov S V 1997 Synthesis, Structure and Reactivity of Binuclear Metal-Metal Bonded Molybdenum(V) and Tungsten(V) thioselenohalides: Molecular structure of $\mathrm{Mo}_{2}\left(\mu-\mathrm{S}_{2}\right)_{2} \mathrm{Cl}_{6}\left(\mathrm{SeCl}_{2}\right)_{2}$ and $\mathrm{W}_{2}\left(\mu-\mathrm{S}_{2}\right)_{2} \mathrm{Cl}_{6}\left(\mathrm{SeCl}_{2}\right)_{2} \mathrm{~J}$. Clust. Sci. 827

49. Young C G, Kocaba T O, Yan X F, Tiekink E R T, Wei L, Murray H H, Coyle C L and Stiefel E I 1994 Bridging Disulfldo Complexes of Molybdenum and Tungsten Formed by Reductive Sulfurization of Oxo-Molybdenum(VI) Complexes and Reductive Desulfurization of Thio(disulfido)-Tungsten(VI) Complexes Inorg. Chem. 33 6252

50. Peldo M A, Shang M and Fehlner T P 2000 Synthesis and structure of $\left[\left(\eta^{5}-\mathrm{C}_{5} \mathrm{Me}_{5}\right) \mathrm{WCl}_{2}(\mu-\mathrm{H})\right]_{2}$. A dinuclear tungsten hydride with a double bond formed from the reaction of $\mathrm{BH}_{3} \mathrm{THF}$ with $\left(\eta^{5}-\mathrm{C}_{5} \mathrm{Me}_{5}\right) \mathrm{WCl}_{4} \mathrm{~J}$. Organomet. Chem. 60977
51. Mondal B, Bag R, Bakthavachalam K, Varghese B and Ghosh S 2017 Synthesis, Structures, and Characterization of Dimeric Neutral Dithiolato-Bridged Tungsten Complexes Eur. J. Inorg. Chem. 5434

52. Gorzellik M, Bock H, Gang L, Nuber B and Ziegler M L 1991 Darstellung und Charakterisierung von zweikernigen Oxo-Komplexen des Molybdän und Wolfram mit Chalkogenen (O, S, Se, Te) als Brückenliganden $J$. Organomet. Chem. $\mathbf{4 1 2} 95$

53. Sokolov M, Virovets A, Nadolinnyi V, Hegetschweiler K, Fedin V, Podberezskaya N and Fedorov V 1994 $\mathrm{Nb}_{2} \mathrm{~S}_{4}{ }^{4+}$ Complexes with 1,1-Dithioacid Ligands Inorg. Chem. 333503

54. Sokolov M, Imoto H, Saito T and Fedorov V 1999 Substitution of bridging $\mathrm{S} 2$ ligands in the $\left[\mathrm{Nb}_{2}(\mu-\right.$ $\left.\left.\mathrm{S}_{2}\right)_{2}\right]^{4+}$ Core: A Simple Route to $\left[\mathrm{Nb}_{2}\left(\mathrm{Se}_{2}\right)_{2}\right]^{4+}$, $\left[\mathrm{Nb}_{2}(\mathrm{~S})\left(\mathrm{Te}_{2}\right)\right]^{4+}$ and $\left[\mathrm{Nb}_{2}(\mathrm{~S})_{2}\right]^{4+}$ J. Chem. Soc., Dalton Trans. 85

55. Nied D and Breher F 2011 New perspectives for "nonclassical" molecules: heavy [1.1.1]propellanes of group 14 Chem. Soc. Rev. 403455

56. Abramov P A, Sokolov M N, Virovets A V, Mirzaeva I V, Kozlova S G, Vicent C and Fedin V P 2014 Reductive selenidation of $\left[\mathrm{Cp}^{*} \mathrm{MoO}_{2} \mathrm{Cl}\right]$ : Synthesis, structure and bonding in new binuclear and trinuclear clusters J. Organomet. Chem. $\mathbf{7 7 0} 94$

57. Messerle L 1988 Metal-Metal Bonded Dinuclear and Organodimetallic Complexes of the Early Transition Metals (Groups 4 and 5): Synthesis, Structure, and Reactivity Chem. Rev. 881229 